\title{
Informatica en het menselijk blikveld
}

Citation for published version (APA):

van den Herik, H. J. (1988). Informatica en het menselijk blikveld. Rijksuniversiteit Limburg. https://doi.org/10.26481/spe.19881021hh

Document status and date:

Published: 21/10/1988

DOI:

10.26481/spe.19881021hh

Document Version:

Publisher's PDF, also known as Version of record

\section{Please check the document version of this publication:}

- A submitted manuscript is the version of the article upon submission and before peer-review. There can be important differences between the submitted version and the official published version of record.

People interested in the research are advised to contact the author for the final version of the publication, or visit the DOI to the publisher's website.

- The final author version and the galley proof are versions of the publication after peer review.

- The final published version features the final layout of the paper including the volume, issue and page numbers.

Link to publication

\footnotetext{
General rights rights.

- You may freely distribute the URL identifying the publication in the public portal. please follow below link for the End User Agreement:

www.umlib.nl/taverne-license

Take down policy

If you believe that this document breaches copyright please contact us at:

repository@maastrichtuniversity.nl

providing details and we will investigate your claim.
}

Copyright and moral rights for the publications made accessible in the public portal are retained by the authors and/or other copyright owners and it is a condition of accessing publications that users recognise and abide by the legal requirements associated with these

- Users may download and print one copy of any publication from the public portal for the purpose of private study or research.

- You may not further distribute the material or use it for any profit-making activity or commercial gain

If the publication is distributed under the terms of Article $25 \mathrm{fa}$ of the Dutch Copyright Act, indicated by the "Taverne" license above, 


\section{INFORMATICA}

\section{EN}

\section{HET MENSELIJK BLIKVELD}


Herik, H.J. van den

Informatica en het menselijk blikveld / H.J. van den Herik; [tek.: Harm Bakker]. - Maastricht: Rijksuniversiteit Limburg, Faculteil der Algemene Wetenschappen. - Tek. Inaugurele rede Maastricht.

ISBN 90-72710-01-0

SISO 527.8 UDC 681.3:159.955(043.5)

Trefw.: Kunstmatige Intelligentie

Uitgegeven door: RijksuniversiteitLimburg Faculteit der Algemene Wetenschappen

Postbus 616 6200 MD Maastricht

Druk en bindwerk: Rijksuniversiteit Limburg, Afdeling Reprografie Typen en opmaak: Hadewych Bollen, Sabine Lebens, Nancy Heesen Omslagontwerp: Harm Bakker

(C) 1988 Hel auteursrecht berust bij de schrijver.

Alle rechten voorbehouden. Niets uit deze uitgave mag worden vervelvoudigd, opgeslagen in cen geautomatiseed gegevensbestand, of openbaar geniakt, in enige vorn of enige wige, hetzij electronisch, mechanisch, door fotokopieç, opmamen, of enig andere manier, zonder vooralgande schrificlijke toestemming van de uitgever.

Voor zover het maken van kopicen uit deze uitgawe is toegestam op grond van anikel 163 Auteurswet $1912 \mathrm{j}$ het Besluit van 20 juni 1974, St.b. 351 , 2oals gewijzigd bij het Bestuit valn 23 augustus 1985, St.b. 471 en arnikel 17 Auteurswet 1912, dient men de dararoor wentelijk verschuldigde vergocdingen te voldoen an de Stichting Reprorecht (Postbus 882, 1180 AW Anstelvecti). Voor het ovememen vam gedcelte(n) wit deze uigaws in bloemlezingen "rcaders en andere compilatiowertken (artikel 16 Autenrsw 1912) dient men zich tot de witgever te wenden.

De afbeelding op de omslag is cen opname van een fractal uit de Mandelbrotverzameling met als gebied $(\operatorname{Re}(-0.730790--0.730700), \operatorname{Im}(0.224394-0.224304)$ ), naar Mandelbrot (1983). 


\section{INFORMATICA}

\section{EN}

\section{HET MENSELIJK BLIKVELD}

\section{Rede}

in verkorte vorm uitgesproken bij de aanvaarding van het ambt van gewoon hoogleraar in de Informatica aan de Faculteit der Algemene Wetenschappen van de Rijksuniversiteit Limburg op vrijdag 21 oktober 1988

door

\section{Dr. H.J. van den Herik}

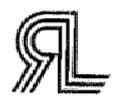

Rijksuniversiteit Limburg, Maastricht, 1988 


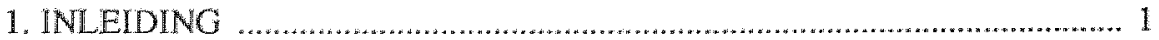

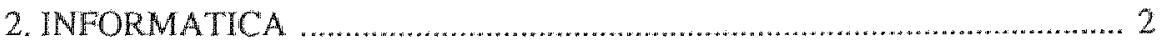

2.1 - Het rekenen op getallen ................................................................ 2

2.2 . Het hanteren van data .................................................................... 3

2.3 - Intelligente handelingen .................................................................... 4

2.4 - De Turing Awards ................................................................................ 4

3. KUNSTMATIGE INTELLIGENTIE (AI) .............................................. 5

3.1 - Enkele definities van $\mathrm{AI}$.................................................................. 5

3.2 - Wat mogen we verwachten? .............................................................. 7

4. HET MENSELIJK BLIK VELD ............................................................. 8

4.1- Begrijpelijkheid en uitwoerbaarheid .............................................. 8

4.2 - Kennis en heuristicken .................................................................... 9

4.3 - Een blik vooruit en terug ......................................................... 10

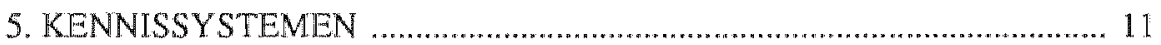

5.1 - Het wezen van kennis ............................................................ 11

5.2 - Ontwikkeling en tockomst ................................................... 12

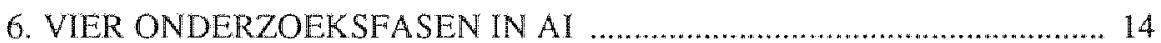

6.1 . Het zoeken ................................................................................ 14

6.2 - De kennisrepresentatic ............................................................ 14

6.3 - Het combineren van zoeken en kennis ........................................... 14

6.4 - Het parallellisme .......................................................................... 14

6.5 - De toekomst ........................................................................... 15

7. SCHAKEN: ONDERZOEKSGEBIED BIJ UITSTEK $\ldots \ldots \ldots \ldots \ldots \ldots \ldots \ldots \ldots \ldots$

7.1 - Waarom computerschaak? ......................................................... 16

7.2 - De verdiensten van computerschaak ............................................. 17

8. ONTWIKKELINGEN EN TOEKOMST ............................................... 19

8.1 - De samenhang tussen Al en informatiesystemen ............................. 19

8.2 - Cognitieve simulatic ............................................................. 20

8.3 - Neurale netwerken en gedistribueerde verwerking ........................... 21

8.4 - Filosolische discussies ............................................................. 23

9. CONCLUSIES EN TOEKOMSTVERWACHTINGEN ............................ 25

10. WOORDEN VAN ERKENTELIJKHEID ........................................ 26

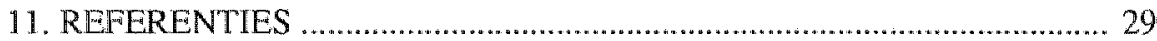


Mijnheer de Rector Magnificus,

Dames en Heren verbonden aan de Rijksuniversiteit Limburg,

en woorts gij allen, die deze plechigheid met uw aanwezigheid hebt willen vereren,

Zeer gewardeerde toehoorders!

\section{INLEIDING}

Het vakgebied van de informatica kent evenmin als dat van de wiskunde een Nobelprijs als hoogste erkenning van uilzonderlijke prestaties, dit in togenstelling tot de natuurkunde, de scheikunde, de economie en de medische wetenschappen. Binnen de informatica heeft men wel een andere onderscheiding gecreeterd, de Turing $A$ ward, die algemeen als gelijkwaardig aan een Nobelprijs geldt.

De Turing Award is in 1966 door de ACM (Association for Computing Machinery) ingesteld en wordt jaarlijks toegekend aan een persoon (of bij uitzondering aan twee personen) voor uitmuntende bijdragen van technische aard aan de informatica-gemeenschap. Bij de aanvaarding van de Award, die een honorarium van US \$ 1000,- met zich meebrengt, spreekt de bekroonde gewoonlijk een rede uit die vervolgens gepubliceerd wordt; van 1966 tot en met 1970 gebeurde dat in de Journal of the ACM en van 1972 tot heden vindt publikatie plaats in de Communications of the ACM.

In 1971 werd de Turing Award toegekend aan John McCarthy voor zijn verdiensten op het gebied van artificiat-intelligence-onderzock. McCarthy aanvaardde de prijs in dank en hicld een enthousiaste rede, getiteld Generality un Artificial Intelligence, maar een publikatie bleef uit. Toen in 1985 ACM Press in sumenwerking met Addison-Wesley Publishing Company evenwel het plan opvatte om een bundeling van alle Turing-lezingen wit te geven, verzocht R.L. Ashenhurst, de redacteur, McCarthy alsnog een tekst van zijn rede in te sturen. McCarthy voldeed aan dit verzoek en vestigde daamee hot record voor de langste tijd iussen het aanwaarden (van de Award) en het volloen aan de verplichlingen. Toch verdient dit voorbeeld geen navolging voor Nederlandse hoogleraren: de tijd ussen benoeming en aanvaarding van het ambt (het uitspreken wan do rede) dient beperkt te blijven. McCarthy (1987) maakte overigens in het begin wan zijn ar tikel al duidelijk wat hem zo lang van publiceren had afgehouden: "Mijn TuringAward-lezing van 1971 had tot litel Algemeenheid in Kunstmatige Intelligentie. Het onderwerp bleek te ambitieus geweest te zijn: ik ontdekte dat ik toen miet in stat was mijn gedachten hierover in behoorlijk geschreven worm te brengen. Hel 
zou beter geweest zijn een overzicht te hebben gegeven van eerder werk en niet iets nieuws geprobeerd te hebben, maar dat lag toen niet in mijn aard. ${ }^{11)}$

Diep inzicht, optimisme en ambitie (vooral de laatste twee) zijn kenmerken van veel artificial-intelligence-onderzoekers. We kunnen ons afvragen of McCarthy met zijn rede eigenlijk niet in de voetsporen van Turing (1950) trad ondat deze inmers in zijn fundamentele artikel Computing. Machinery and Intelligence opmerkte (of voorspelde): "De oorspronkelijke vraag kunnen machines denken? daarvan geloof ik dat die te zinloos is om ook maar een bespreking waard te zijn. Niettemin geloof ik dat aan het eind van deze ceuw zowel het woordgebruik als de algemene verlichte opinie zover veranderd zullen zijn dat men zal kunnen spreken over het denken van machines zonder te verwachten dat men zal worden tegengesproken."

In 1950 was dit een uiterst uitdagende opmerking. Maar inderdaad, slechts de nauwgezente onderzoeker of de oudere generatie geeft tegenwoordig nog met aanhalingstekens aan dat de machine "denkt" of het programma "denkt", daarmee stipulerend dat "denken" in een metaforische zin gebruikt. wordt. Hoewel het nog steeds onjuist is schrijven velen gewoon: de machine denkt, of zou dit laatste toch juist zijn? Om enig inzicht in deze kwestie te krijgen, ga ik hieronder nader in op de ontwikkelingen binnen de informatica en in het bijzonder binnen de kunstmatige intelligentie, voortaan afgekort als AI (Artificial Intelligence). Vervolgens laat ik zien dat echte AI-programma's binnen het menselijk blikveld behoren te liggen. Dat dit in de praktijk niet altijd gerealiseerd wordt, doet daar niets aan af. Als voorbeelden van Al-programma's worden kennissystemen en schaakprogramma's genomen. Deze illustratieve voorbeelden leveren ons verbanden met andere informatica-toepassingen.

\section{INFORMATICA}

Informatica is een jonge tak van wetenschap, die niet kan bogen op een rijke traditie zoals de wiskunde. In de afgelopen vijftig jaar heeft zij zich niettemin in ijltempo een essentiéle plaats weten te verwerven te midden van vele andere wetenschappen. Daarnaast hebben informatica-ontwikkelingen een bijzonder grote invloed gekregen op de samenleving.

\subsection{Het rekenen op getallen}

De gedachte om een computer te gebruiken voor rekenen en wat daartoe te herleiden is stamt uit de vorige eeuw en wordt doorgaans toegeschreven aan Charles Babbage (1791-1871). A.A. Verrijn Stuart (1971) en R.P. van de Riet (1971) hebben in hun oraties uitvoerig aandacht besteed aan de bijdragen die Babbage geleverd heeft aan de informatica-gemeenschap. Zij deden dit naar aanleiding van de honderdste sterfdag van Babbage (18 oktober 1971).

Orschoon Babbage zijn ideeèn vorm gegeven heeft in het ontwerpen van cen Difference Engine en een Analytical Engine, viel de belangstelling voor zijn werk,

1) Citaten zijn in luet algemeen in vertaling gegeven; de verwijzingen zijn echter naar de oorspronkelijke literatur onder opgave van de oorspronkelijke paginering. 
toen de computer enmanl gerealiseerd was (1940), aanvankelijk alleen op de Dif ference Engine: het gebruik wan een computer voor rekenoperatios. In do beginperiode noemden sommigen de computers daarom wel ondcugend "rekenuig". Omstreeks 1940 begon het allemaal aarzelend met optellen, aftrekken, vermenigvuldigen, etc; in de jaren wijtig en zestig zette deze ontwikkeling zich voor in de numerieke analyse, met name in matrixbewerkingen, het oplossen wan differenthalvergeligkingen, etc. Dit alles leidde mede tot programma"s zoals MACS YMA en REDUCE (tegenwoordig op personal computers verkrigbaar), waarbij het "intelligent" oplossen van moeilijke, formele wiskundige opgaven vaak geen probleem meer vormt.

\subsection{Het hanteren van data}

Toen omstreeks 1950 duidelijk werd dat computers goed ingezet konden worden bij rekenopdrachten, kwam de gedachte op om ze niet alleen met getallen maar ook met onbecijferbare data le laten manipuleren. Dit was een belangrijke ontwikkeling, want data vervullen in iedere organisatie een sleutelfunctie en gelden als mede-beleidsbepalend.

Vanzelfsprekend vonden de eerste toepassingen in de jaren vijfig en zestig plaats in cijferijke omgevingen, zoals de financielle afdelingen. Maar al spoedig ontwikkelden computersystemen zich van envoudige data-gerichte systemen tot modeme database-management-systemen. Een van de grote problemen bij zulke database-management-systemen is het realiseren van een omgangsworm met de gebruker. Gebrukers weten doorgaans weinig van computersystemen en meestal nog minder van database-management-systemen. Daarom zou het idean zijn als zij in cen natuurlijke taal (b.v. Nederlands) vragen aan de database zouden kunnen stellen en zo mogelijk passend beantwoord zouden zien.

Bachman (1973) beschreef in zijn Turing-lezing de programmeur als een loods in het database-Systeem; de gebruiker zou cvenwel niets van de mocilijk bevaarbare gronden in het systeem behoeven te weten en (met een beperkic, op het Nederlands georiénteerde taal) antwoord, indien anwezig in de clatabase, dienen te krijgen op de vraag: "Toon me de verkoop in 1988 van huppels in Zuid Limburg".

Moderne ontwikkelingen leggen de nadruk op intelligente omgangsvormen. Dit betekent dat de vraagtaal tamelijk rijk mag zijn en dat or ook een passend antwoord tenugkomt als het gevraagde niet aanwezig is (b.w. wawrom hot nict aanwezig is, of de tegenvraag 'bedoelt u misschien ...?'). Het grote probleem bij het modelleren en formaliseren is de menselijke flexibiliteit (Wejuers, 1988). De vakgroep informatica van de Rijksuniversiteit Limburg doet op dit gebied mee un een ESPRIT II-project, getiteld MACS (Maintenance Assistance Capability for Sofware), en houdt zich daarbij o.a. bezig met menselijke factoren in intelligente omgangsvormen. 


\subsection{Intelligente handelingen}

Eveneens omstreeks 1950 kwamen enkele onderzoekers op de idee dat computers behalve voor het omgaan met getallen en data ook gebruikt zouden kunnen worden voor het behandelen van kennis. Deze gedachte is door Shannon en" Turing ongeveer tegellijkerijd beschreven. Beiden kunnen dan ook ex aequo gezien worden als grondleggers van de artificial intelligence.

Zij publiceerden de uitwerking van hun gedachten niet in wiskundige, maar in filosofische tijdschriften (informaticatijdschriften waren er nog helemaal niet). Hoewel beide geleerden het schaken als voorbeeld bij uitstek beschouwden van niet louter rekenen, maar vooral van het daaruit voortvloeiend intelligent handelen (denken), beschreef Turing (1950) zijn denkbeelden in brede zin, zoals gezegd, onder de titel Computing Machinery and Intelligence. Met name de ondertitel Can machines think? bracht veel pennen in beweging; deze discussie is overigens nog steeds actueel. Shannon (1950) schreef over een directe toepassing onder de titel Programming a Computer for Playing Chess. Later deed Turing (1953) dat eveneens, maar Shannons artikel had prioriteit, ondanks een uitspraak van Turings rechterhand, I. J. Good, dat Turing de gedachte aan schaakspelende computers al in 1944 had ontwikkeld en dat hij, Good, hem van publikatie had afgehouden, ondat de algoritme hem te zeer voor de hand liggend leek.

Tegenwoordig stat het intelligent handelend onderdeel van de informatica sterk in de belangstelling. In hoofdstuk 3 gaan we nader in op de ontwikkelingen binnen de kunstmatige intelligentie en in paragraaf 8.1 zullen we de samenhang tussen de drie hierboven genoemde informatica-gebieden opnieuw bezien.

\subsection{De Turing Awards}

Hoewel het begip computer in de informatica cen centrale plaats inneemt, is het nicttemin een zeer moeilijk te definieren begrip. Misschien zou de door Turing (1936) gegeven theoretische beschrijving van een Turing-machine nog het meest geschikt zijn om aan cen streven naar eenheid tegemoet te komen. Dit zou dan eens te meer de nadruk leggen op Turings unieke voortrekkersrol in de informatica.

Mocht uit de Inleiding en paragraaf 2.3 de indruk zijn ontstaan dat de Turing Award voornamelijk wordt toegekend aan Al-onderzoekers, dan vermeld ik nogmals dat het gaat om uitmuntende bijdragen van technische aard aan de informatica-gemeenschap. De Turing-Award-toekenningen hebben dan ook plaats gevonden op alle drie behandelde gebieden, ook te omschrijven als: de numerieke algoritmen, de database-ontwikkelingen en de kunstmatige intelligentie.

In figuur 1 geven wij de lijst van namen, zonder verder op de verdiensten van de genoemden in te gaan. Daarvoor zij verwezen naar ACM Turing Award Lectures, The First Twenty Years 1966-1985 (Ashenhurst en Graham, 1987). De lijst is representatief voor de ontwikkeling van het hele vakgebied informatica. 


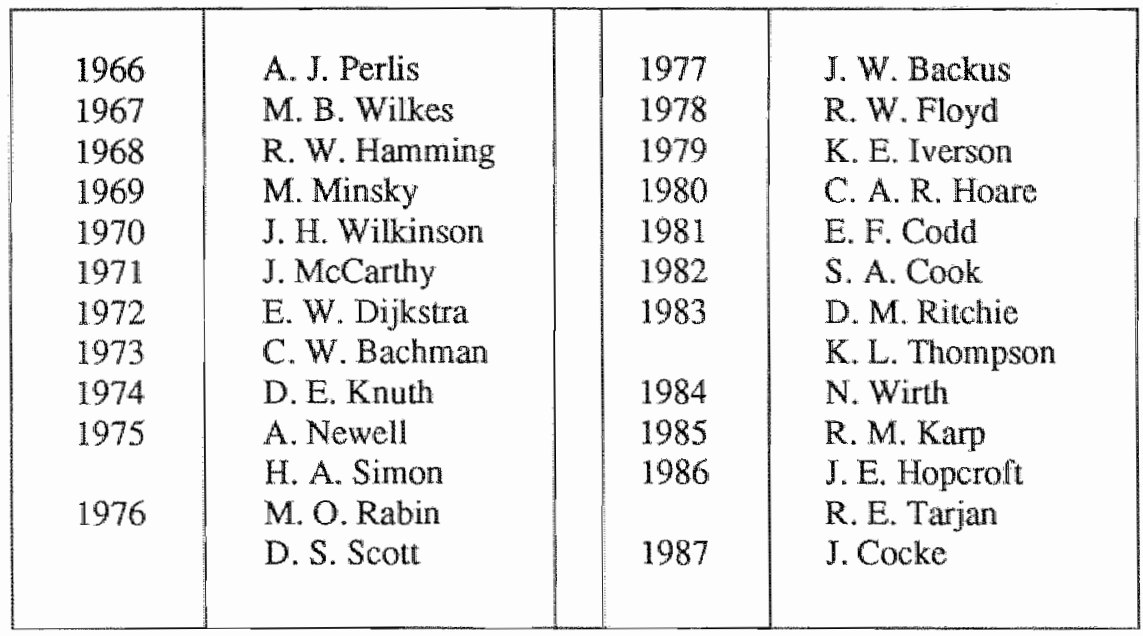

Figuur 1: Turing-Award-winnaars 1966-1987.

\section{KUNSTMATIGE INTELLIGENTIE (AI)}

Het verwijzen naar Turings (1936) theoretische definitie van het begrip computer ligt tegenwoordig niet voor de hand, maar bij nader inzien blijkt de definitie sluitend te zijn; bovendien is zij tot dusver niet wezenlijk verbeterd.

Bij de beantwoording van de wraag: Wat is kunstmatige imelligentie? ligt het evenwel geheel anders. Afgezien van het feit dat psychologen niet over een goede, algemeen geaccepteerde definitie van het begrip intelligentie beschikken, is het gebruik wan de term arfificial intelligence op zichzelf al aanvechtbaar gesteld (cf. Mars, 1987). Dit moge zo zijn; redenen om de term toch te gebruiken zijn niet alleen gelegen in de gebruikelijkheid, maar vooral in het verweer dat "een grondpijler van het AI-gebied de overtuiging is dat opgaven, die vereisen wat wij intelIigente handelingen zouden noemen, tot op zekere hoogte bestudeerd kunnen worden, en wel onafhankelijk van organismen als mensen en de wijze waarop zij zulke taken vervullen" (Arcten, 1980, p. 423).

\subsection{Enkele definities wan $\mathbf{A I}$}

Er zijn misschien wel evenveel definities van AI in omloop als er onderzockers zijn. Ik zal mij tot enkele beperken om de problematiek aan te geven. De delinitie van Mars (1987) die ook reeds eerder door anderen was voorgesteld (cf. Findler en Meltzer, 1971) luidt: "Artificial Intelligence is dat deel van de informatica waarin computerprogramma's worden vervaardigd voor het verrichten van taken, waarvan tien jaar geleden gedacht werd dat er intelligentie voor vereist was". Met deze definitie ben ik het in velerlei opzichten niet eens. Een database-programma dat het schaakeindspel Timman-Velimirovic Ceilloos (dus beter dan Timman) uitspeelt, bevat weliswalr een enorme hoeveelheid kennis maar vertoont geen enkele intelligente handeling (cf. Van den Herik et al., 1987). 
Hoe moeilijk het is om tot ecn definitie te komen, wil ik hieronder laten zien door drie definities (zie figuur 2) met elkaar te vergelijken. Ze zijn ontleend aan Rich (1983), Van den Herik (1984) en Winston (1984).

\section{Rich : AI bestudeert hoe we computers dingen laten doen die mensen nu nog beter kunnen. \\ Van den Herik: Al bestudeert ideeën die ons inzicht in menselijke denkprocessen verbeteren.}

Winston : AI bestudeert ideeën die computers intelligent kunnen maken.

Figuur 2: Drie definities van artificiall intelligence.

Hoewel alle drie definities artificial intelligence als uitgangspunt hebben, geeft de formulering duidelijk aan dat de doelstellingen van de onderzoekers totaal verschillend zijn. Deze doelstellingen zijn opgenomen in figuur 3 .

Rich : Het oplossen van moeilijke problemen.

Van den Herik: Het maken van programma"s die binnen het menselijk blikveld vallen (d.w.z. de programmatekst moet voor mensen begrijpelijk en uitvoerbaar zijn).

Winston : Het begrijpen van principes die intelligentie mogelijk maken.

Figuur 3: Drie doelstellingen behorende bij de drie definities van figuur 2.

Bij Rich ligt de nadruk op het voor computers toegankelijk maken van problemen waarbij mensen tot dusver superieur zijn gebleken; daarbij wordt afgezien van de manier waarop de problemen opgelost worden. Bij Winston gaat het erom de fundamenten van het begrip intelligentie bloot te leggen, ongeacht de vraag in wie of wat die intelligentie fungeert. Mijn eigen definitie bevindt zich tussen Rich en Winston in. Voorop staat bij mij dat er computerprogramma's gemaakt dienen te worden, die kunnen wat mensen ook kunnen, maar daarnaast moet de werkwijze binnen het programma ook enige verbetering van inzicht geven in de manier waarop mensen redeneren. Dit betekent:

\section{niet dat}

(i) een mens noodzakelijkerwijze kennis zo hanteert als het programma dat doet, maar dat

(ii) een mens het volgens het gerealiseerde model zou kunnen doen.

Het nadeel van mijn definitie en doelstelling is dat er cen nieuwe term, menselijk blikveld, wordt ingevoerd (zie hoofdstuk 4). Hiertegenover staat dat door mijn 
definitie de plaats van Al-programma's binnen de informatica nauwkeuriger kant worden aangegeven (zie eveneens hoofdstuk 4).

\subsection{Wat mogen we verwachten?}

Een AI-programma voert slechts intelligente handelingen uit binnen een beperkt domein. Veronderstel nu eens, dat we in staat zouden zijn zo een domein, warbinnen het mogelijk is tot niet-triviale resultaten te komen, volledig te modelleren. Het domein kan dan beschouwd worden als een microwereld waarin inteliigente handelingen vergeleken kunnen worden met menselijke handelingen (preciezer gezegd: met resultaten van het menselijk denken) binnen het betreffende domein. Er is als het ware sprake van een schaalverkleining in het denken. Op dit punt aangekomen zijn er twee methoden om te trachten te komen tot het verkrijgen van inzicht in het menselijk denken:

(i) door generalisering van een microwereld;

(ii) door samenvoeging van een groot aantal microwerelden.

Zij die de aanspraken van AI-onderzoekers principieel bestrijden stellen dat beide wegen onbegaanbaar zijn (cf. o.a. Dreyfus, 1980). Hieronder lichten we hun argumenten toe, waarbij enige nadruk valt op de microwereld van het schaakspel, die ook door Dreyfus $(1980$, p. 74$)$ als voorbeeld wordt aanvaard.

ad (i) De onmogelijkheid van generalisering.

De microwereld wan het schaakspel zou zo zeer op zichzelf staan en het schaakdenken zou zo weinig met denken in het algemeen te maken hebben, dat zelfs als we inzicht zouden hebben in de wijze waarop een schaakspeler "schaakdenkt" we nog niets zouden weten over de wijze waarop een menselijke schaker denkt, laat staan over de wijze waarop een mens denkt.

ad (ii) Het holistische tegenargument.

Gesteld dat we van een groot aantal isoleerbare deelgebieden volledige kennis zouden bezitten (b.v. schaken, vertalen, samenvatten, etc.) dan behoeft een formele vereniging van al die resultaten niet noodzakelijkerwijs te leiden tot enig resultaat voor het denken in het algemeen; immers, de verschillende vermogens vormen bij het menselijk denken via hun gecompliceerde onderlinge verbanden wellicht een geheel, dat meer zou kunnen zijn dan de som der delen.

In het kader van deze rede heb ik niet de pretentie een bijdrage te leveren aan deze filosofische discussie. Enige resultaten en wat we verder mogen verwachten komen in hoofdstuk $7 \mathrm{cn} 8$ opnieuw aan de orde.

Voor de volledigheid vermelden we nog het bestaan van andersoortige principièle bestrijders van AI, namelijk zij die zich baseren op cen beweerde onmogelijkheid (Bar-Hillel, 1960); in zijn eenvoudigste vorm luidt hun bewering: "Computers zullen nooit in staat zijn taken van het type $x$ te realiseren" (Dreyfus, 1972). Hierover kunnen we kort zijn: natuurlijk zullen er taken zijn die geen computer ooit zal kunnen verrichten, maar de grens is onbepaald. Voor een uitgebreide bespreking over de grens tussen mogelijk en onmogelijk verwijzen we naar Hofstadter (1979, pp. 600-601) en Van den Herik (1983, pp. 230-235). 


\section{HET MENSELIJK BLIKVELD}

In de beschrijving van het na te streven Al-doel hebben we gebruik gemaakt van het begrip menselijk blikveld. Deze term is een vertaling van Michie's (1982) Human Window, geintroduceerd op de Third Conference on Advances in Computer Chess (London, 1981), bij de bespreking van het KPK-eindspel (Koning en Pion tegen Koning). Wij zullen het menselijk blikveld hieronder toelichten met het spel boter, kaas en cieren (in het Engels: tic-tac-toe).

\subsection{Begrijpelijkheid en ü̈tvoerbaarheid}

Programma-ontwerpers hebben steevast te maken met cen tweespalt in hun computergebruik:

(i.) bij veel berekeningen is maar weinig geheugen nodig (A);

(ii) bij weinig rekenen is veel geheugen vereist $(\mathbb{Z})$;

wil in beide gevallen het resultaat hetzelfde zijn.

Dit dilemma is geen dichotomie. Het speelt zich af in het spectrum tussen $A$ en $Z$, waarbij vrijwel alle tussenoplossingen even goed mogelijk zijn (zie figuur 4).

veel berekeningen

A -

weinig geheugen weinig berekeningen

veell geheugen

Figuur 4: Het spectrum berekening-geheugen.

Aan de A-kant van het spectum (figuur 4) onderzoeken we alle varianten vanuit de beginstelling en stellen we op grond daarvan de speltheoretische waarde van boter, kaas en eieren vast (in de zin van von Neumann en Morgenstern (1944)) en bepalen we de/een beste zet. (Bij een beste zet is sprake van cquipollentic.) Voor een mens is het wel begrijpelijk hoe het programma tot zijn zet gekomen is, maar voor dezelfde mens is, door de overmat aan berekeningen, zo een onoverzienbate serie opdrachten nooit wilvoerbaar.

Aan de Z-kant van het spectrum hebben we cen database (een lijst van posities mel bij elke posilie de/een beste zel) aangegeven. Het programma behoeft slechts de lijst na te gaan om de/een beste voorzetting te spelen. Het zoeken in zo een lijst is voor een mens eveneens gemakkelijk witvoerbaar, daarbij komt het echter vaak woor dat de (strategische) bedoeling van de voorgeschreven zet voor cen mons nier begripelijk is.

Er zijn natuurlijk allerlei passende algoritmen om minder extreme strategieèn dan A of $Z$ gestalle te geven. Vanuit de machine gezien ruilen die geheugenbeslag in tegen wat meer berekeningen naarmate ze zich van $Z$ naar $A$ begeven. Onze ervaring leert ons dat zo lang we maar weinig van $Z$ naar $A$ bewegen, de begrijpellikheid voor een mens slechts langzaam toeneemt en eveneens dat naarmate we van A naar rechts gaan dit begrijpelijk zijn voor een mens betrekkelijk langzaam afneemt. Of we het nu vanuit $A$ of vanuit $Z$ benaderen, er zijn punten binnen het spectrum $\mathrm{A}-\mathrm{Z}$, warin de berekening menselijk begrijpelijk blijft en menselijk witvoerbaar is. 
Figuur 5 toont dit spectrum dat, eenmaal bepaald, ons leidt tot de volgende pragmatische definitie.

Indien een programma uitsluitend concepten bevat zo dat

(i) de programmatekst (eventueel becommentarieerd) begrijpelijk is voor een mens (d.w.z. een mens begrijpt hoe een programma tot zijn zet komt)

en

(ii) de opdrachten in het programma uitvoerbaar zijn voor een mens (d.w.z. een mens is in staat te vinden welke zet gespeeld dient te worden)

dan definiëren wij dat de aan de zet ten grondslag liggende concepten en de daarmee verbonden uitwoeringspraktijken binnen het menselijk blikveld liggen.

\begin{tabular}{|l|r|r|}
\hline berekening \\
begrijpelijk \\
voor een mens
\end{tabular}

Figuur 5: Het menselijk blikveld.

In figuur 5 zien we dat er een gebied is aangegeven met de eigenschap dat de programmaconcepten begrijpelijk zijn voor een mens en de programma-opdrachten uitvoerbaar voor een mens. De grootte van het menselijk blikveld alsmede de plaatsbepaling zijn echter alleen schematisch aangegeven. Wij zijn van mening dat deze methode ons de mogelijkheid biedt om tot een gemene mat te komen die bruikbaar is voor het vergelijken van AI-programma's binnen een bepaalde microwereld.

\subsection{Kennis en heuristieken}

In de praktijk (Rich, 1983; Van den Herik, 1983; 1984) is gebleken dat een AIprogramma, will het binnen het menselijk blikveld vallen, aan drie belangrijke eisen dient te voldoen:

(i) het bezit van een passende zoekprocedure;

(ii) het adequaat gebruik van relevante kennis;

beide reeds eerder besproken; daarenboven blijkt het

(iii) mogelijkheden tot abstractie

in te moeten houden, zodat in het gegeven voorbeeld een overgang van een tweedimensionaal naar een n-dimensionaal boter, kaas en eieren-programma zonder te veel moeite mogelijk is. 
Wat relevante kennis ook zij, voor het vakgebied AI kan kennis met wrucht verdeeld worden in drie, ten dele helaas overlappende onderverzamelingen (Van den Herik, 1985), namelijk:

(a) kennis in de vorm van onbetwistbare feiten (facts);

(b) kennis in de vorm van ervaringsregels (heuristics);

(c) kennis in de vorm van overtuigingen (beliefs).

In Al-programma's treffen wij meestal alleen feiten en ervaringsregels aan, waarbij de laatste, vaak heuristieken genaamd, een belangrijke rol spelen. Hieronder geef ik een eenvoudig voorbeeld van een boter, kaas en eieren-programma dat op zichzelf binnen het menselijk blikveld valt, maar dat niet korrekt speelt vanwege de geimplementeerde heuristieken.

In boter, kaas en eieren lijken twee overheersende heuristieken te zijn:

H1: Het centrale veld is heel belangrijk.

H2: De hoekvelden zijn belangrijker dan de andere randveiden.

Een 1-ply-diep zoekproces (d.w.z. er wordt slechts ến halve zet voonuigekeken) verloopt nu als volgt $(X$ is een sterke speler, $O$ maakt slechts gebruik van $H 1$ en H2).

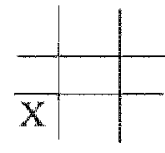

zet 1

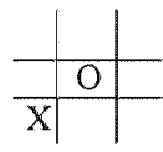

zet 2

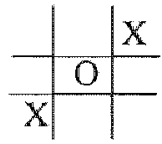

zet 3

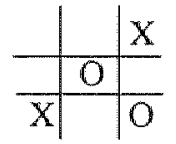

zet 4

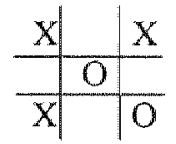

zet 5

en $\mathrm{X}$ wint.

We weten dat boter, kaas en eieren als theoretische uitkomst remise heeft; O moet dus ergens een fout gemaakt hebben: was dat bij zet 2 of bij zet 4 ?

Nadere beschouwing wijst uit dat het bij zet 4 fout gegaan is. De eerste conclusie is in ieder geval dat $\mathrm{H} 1$ en $\mathrm{H} 2$ te klakkeloos zijn toegepast. Deze fout kan verholpen worden door (a) een dieper zoekproces toe te passen of (b) $\mathrm{H} 2$ beter te formuleren (meer kennis aan het systeem toe te voegen), maar het blijkt dat dit meer voeten in de aarde heeft dan op het eerste gezicht bij een zo eenvoudig spel wel lijkt.

Onze tweede conclusie uit dit voorbeeld is dat we wel moeten aannemen dat AIprogramma's, gebaseerd op heuristieken, niet altijd de beste beslissingen nemen.

\subsection{Een blik vooruit en terug}

Het menselijk blikveld is in 4.2 slechis ten dele blootgelegd. Het menselijk blikveld houdt voor mij meer in, namelijk de uitbreiding van de informatica onder de 
niet-wakgenoten. De informatica als geheel komt steeds meer in ieders blikveld te liggen: in veel huizen staat een personal computer voor doelgericht gebruk (voor notulen, voor vergaderingen en voor wat van het dagelijks werk naar huis is meegenomen, etc.), maar ook veelal voor spel en ontspanning. Deze ontwikkeling zal zich in de jaren negentig gestadig voortzetten.

Hoewel de vaag wat ons precies te wachten stat vanzelfsprekend niet afdoende beantwoord kan worden, zijn or wel en aantal verwachtingen te formuleren op grond van de lhuidige stand van zaken. Om deze verwachtingen verantwoord te presenteren zullen ze in samenhang met cen terugblik beschreven worden. We geven hieronder eerst een kort overzicht van deze samenhang.

In hoofdstuk 5 schenken we aandacht aan een informatica-toepassing (kennissystemen), terwijl in hoofdstuk 6 de ontwikkeling van de kenmerkende Al-onderzoeksfasen nader beschouwd wordt. Het schaken wordt in hoofdstuk 7 als onderzoeksgebied bij nitstek gepresenteerd, waarin we de vier fasen van hoofdstuk 6 opnieuw herkennen. Er zal voorts worden aangegeven welke technieken binnen de AI ontwikkeld zijn die toepassingen elders vinden/gevonden hebben. In hoofdstuk 8 volgt dan de onderlinge samenhang van de informatica-ontwikkeling (numerieke algoritmen in combinatie met databases en intelligente handelingen), gevolgd door een nadere plaatsbepaling en toekomstverwachting van AI en informatica ten aanzien wan andere takken van wetenschap. Een en ander gezien vanuit de speciale blikrichting van mijn leerstoel, waarin immers Al centraal staat.

\section{KENNISSYSTEMEN}

Eeuwenlang hebben filosofen, psychologen, logici en vele andere onderzoekers geworsteld met de vraag: Wat is kennis? Eerst onlangs (zeg zo een 50 jaar geleden) hebben informatici zich ook op deze vraag gestort, aanvankelijk schuchter, maar naarmate door bescheiden worderingen de moeilijkheden duidelijker werden, met grotere inzet en hardnckkigheid. Het begrip kennis bleek ook in hun context hoe langer hoe meer wluchtig en ongrijpbaar. Veel Al-onderzoekers begonnent met enthousiasme aan het probleem van de kennisrepresentatie en ontdekten niet zelden "opnienw" dat kennis en zoeken op een opmerkelijk gecompliceerde manier samenhangen.

\subsection{Het wezen van kennis}

Uiteraard moet ik in deze rede de werleiding weerstaan om het thema van de kennissystemen een plaats te geven in (de geschiedenis van) de epistemologie. Maar die verleiding is sterk, ik denk aan het aprioristische model van Plato's idecenleer, aan het empiri(ci)stische model - in Plato's dialoog Meno - van her zoeken naar de definitie van de äpet7́ ( = deugdelijkheid; beter : hoogste prestatieniveau ) en aan de sceptische passage in deze dialoog: zo een definitie kunnen we niet zocken, want of we weten al wat ópetí is en dan behoeven we niet meer te zoeken of we weten niet wat ópetí is en dan weten we niet waar we naar moeten zoeken. 
Ondanks het feit dat Socrates veel aandacht besteedt aan het zoeken van kennis, legt hij tenslotte toch de nadruk op de herinnering, de look-up; in onze terminologie is dat de rechterkant ( $Z$-kant) van het spectrum. Maar Socrates besteedt ook aandacht aan de vraag: is kennis altijd iets dat anderen je leren (het empiricistische model), of kun je kennis in een of andere vorm al van meet af aan bezitten (het aprioristische model)?

\subsection{Ontwikkeling en toekomst}

In de ontwikkeling van kennissystemen (expertsystemen) binnen de artificial intelligence komen we de tegenstelling van beide laatstgenoemde modellen van menselijke kennis voortdurend tegen. Het moet daarenboven volgens sommigen niet uitgesloten worden geacht dat directe machine-interacties (onderling communicerende Al-programma's) leiden tot kennis van een nieuwe soort, die geen overeenkomst heeft met enige menselijke kennis en zelfs zelfkennis zou kunnen inhouden. Om deze speculatieve bewering toe te lichten geef ik in figuur 6 een schematisch overzicht van de ontwikkeling van expertsystemen binnen AI.

We veronderstellen hierbij de volgende dichotomie binnen het AI-onderzoek:

(1.) De nadruk vall op menselijke intelligentie.

Het streven is dat AI-programma's (in beginsel) een theorie over het menselijk denken vormen.

(2) De nadruk valt op machine-intelligentie.

Het streven is dat AI-programma's het menselijk denken evenaren (Europa) of overtreffen (Amerika) - bij het tot stand komen van de handelingen wordt afgezien van het menselijk denken.

Voor een beschrijving van de diverse programma's verwijzen wij naar de vakliteratuur (Arden, 1980; Barr en Feigenbaum, 1981, 1982; Cohen en Feigenbaum, 1982; Van den Herik, 1983, 1984). Uit figuur 6 valt af te lezen dat op het ogenblik de nadruk valt op het sluizen van de kennis van een menselijke expert in een programma. Hot gaat hier om het achterhalen van feiten, heuristieken en vooral om thet op het spoor komen van verbanden tussen feiten en heuristieken. Deze taak wordt nu verricht door een knowledge engineer; aan de Universiteit van Amsterdam wordt aandacht besteed aan het formaliseren van de kernisontsluitingssystemen (Wielinga en Breuker, 1986).

Ook kennisontsluiting is volgens Quinlan (1984) en Michie (1987) inductief programmcerbaar. Dit zou, indien juist gebleken, een volledige overgang betekenen van de nadruk op menselijke intelligentie naar de nadruk op machineintelligentie. Ik verwacht dat deze overgang tussen 1995 en 2000 voor een groot deel verwezenlijkt zal worden. Met de vermelding van de parallelle verwerking in figuur 6 geven we niet alleen de huidige stand van onderzoek aan (cf. Henseler et al., 1988), zoals die in het volgende hoofdstuk besproken wordt, maar wijzen we tevens op een analogie tussen parallelle kenniswerwerking bij mensen en bij computers. 


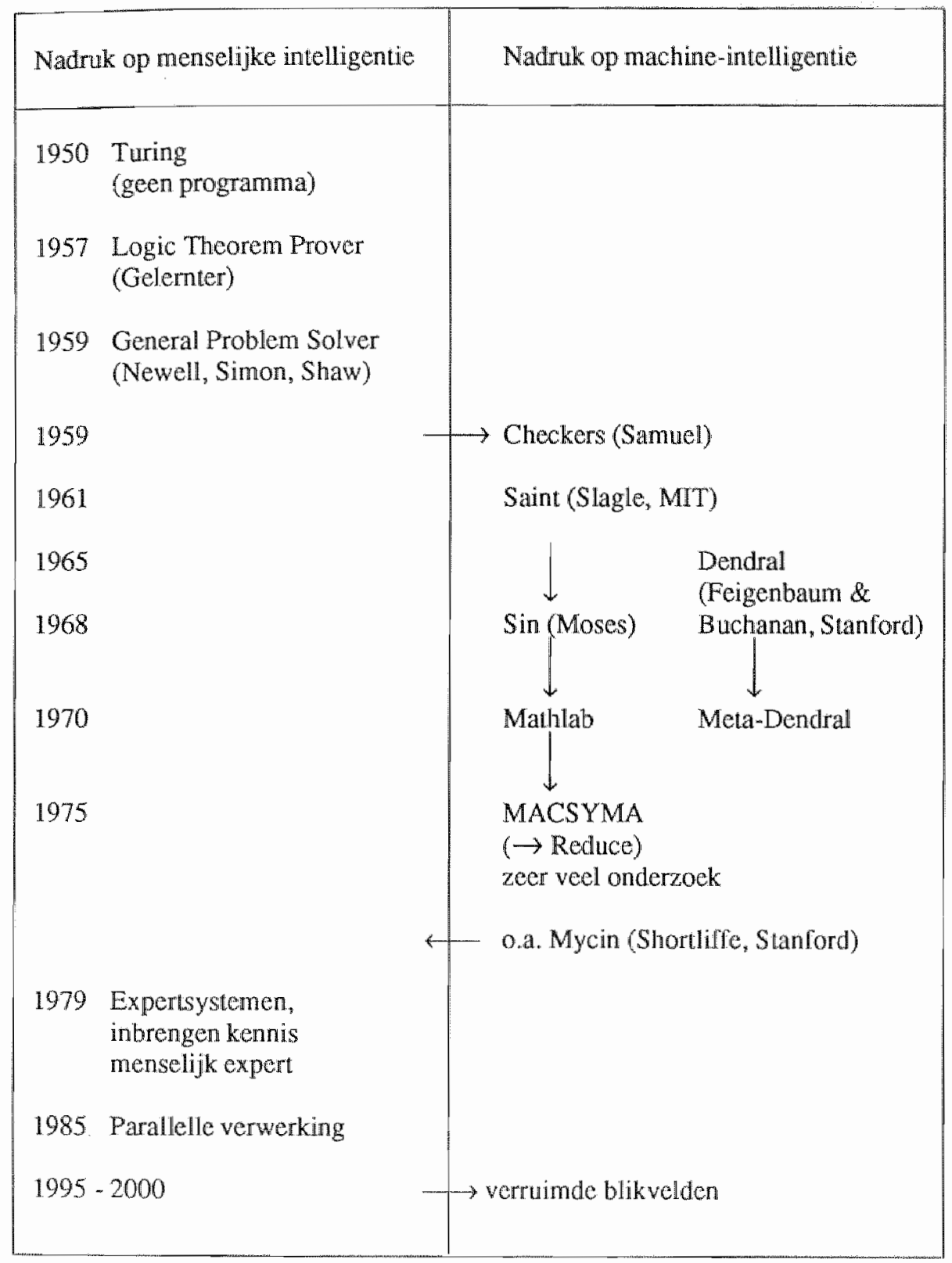

Figuur 6: Ontwikkeling van expertsystemen birnen Al. 


\section{VIER ONDERZOEKSFASEN IN AI}

De ontwikkeling van Al-programma's is natuurlijk nauw verbonden met de ideednontwikkeling op het betreffende gebied, maar ook met de technologische ontwikkeling van computers. Omstreeks 1950 waren er vier Al-onderzoeksgebieden (schaken, dammen, het bewijzen van wiskundige stellingen en het vertalen), waarbinnen getracht werd inzicht te verkrijgen in het menselijk denken.

\subsection{Het zoeken}

In de eerste jaren (1950-1960) dacht men dat het erom ging een groot aantal mogelijkheden te onderzoeken en dan een beslissing te nemen. Van schaken tot vertalen werd het Al-onderzoek gezien als zoekprobleem (schaken: veel stellingen onderzocken; wertalen: zoeken in een groot woordenboek). Ook andere problemen die aan het eind van de jaren vijftig aan de Al-onderzoekslijst werden toegevoegd (b.v. het GPS-programma (Newell en Simon, 1972)) werden behandeld als zoek. problemen. Het gevolg was dat er een groot aantal mooie zoektechnieken ontwikkeld en geformaliseerd werd (minimax-algoritme, $\alpha-\beta$ algoritme, branch-andbound algoritme, etc.).

\subsection{De kennisirepresentatie}

Toen men, halverwege de jaren zestig, begon te onderkennen dat dit zoeken niet tot de verwachte intelligente programma"s leidde, wond er een verschuiving plats van zocktechnieken naar kennisrepresentatie.

De gedachte was dat, als nu maar genoeg vakkennis op hoog niveau in een programma ingebracht werd, er "vanzelf" een betere oplosising van het probleem (zetkeuzeprobleem/vertaalprobleem) te voorschijn zou komen. Dit bleek slechts in zeer beperkte mate waar; in feite gelukte het niet om het kennisrepresentatieprobleem op tc lossen.

\subsection{Het combineren van zoeken en kennis}

In de jaren zeventig werden partiële successen geboekt door het combineren van speciale kennisrepresentaties en zoektechnieken. Op deelgebieden (b.x. schaakeindspeldomeinen, Winograd's (1972) blokkenwereld) leiddle dit tot zeer goede prestaties, maar de nieuwe techniek bleek ten enenmale onvoldoende woor een groot complex domein, zoals het schaken of het vertalen.

\subsection{Het parallellisme}

In 1980 legde de Turing-Award-winnaar van 1983, Ken Thompson, met het programma Belle voor het eerst weer de nadruk op snelheidsvergroting in het zoekproces. Terwijl schaakgrootmeesters per zet slechts een beperkt aantal warianten onderzoeken, doorloopt Belle zo"n 150.000 stellingen per seconde. Kortom, het is ongelooflijk wat Belle allemaal "ziet" en vooral wat het programma "niet ziet". Het idee van snelheidsvergroting zette zich door via twee wegen: supercomputers en parallellisme. De kracht die bij een supercomputer vrijkomt, wordt 
yooral benut door reken-intensieve programma's, waarbinnen ook AI-toepassingen een rol spelen (Hyatt, 1985; Dekker et al., 1987).

Ook in Nederland is er (veel) activiteit op dit gebied. In de toekomst blijft de Rijksuniversiteit Limburg, die het bellang van beide ontwikkelingen inziet (Van den Herik, 1988b), dan ook participeren in het HYDRA-project zoals dat aan de TU Delft ontwikkeld is. HYDRA is een acroniem voor HYpothesis Deduction through Rule Application. Dit parallelle project kent een hardware/numerieke component in de vorm van het leveren van specificaties voor het DPP-project (Delftse Parallelle Processor) (Dekker, 1985) en een software-component: het ontwikkelen van parallelle AI-algoritmen (Hofland, 1987). Een aantal van deze ideeën zijn gerealiseerd op cen NCube/4+ (Henseler et al., 1987).

\subsection{De toekomst}

Vele onderzoekers hebben zich de laatste vijf jaar gebogen over de vraag welke parallellismen zich het best lenen voor gelijktijdig zoeken in een n-processor machine (Marsland en Popowich, 1985; Newborn, 1985; Bal en Van Renesse, 1986; Schaeffer, 1987). Daarbij traden vier aspecten aan het licht die een nader onderzoek vereisten: communicatie-overhead, search-overhead, synchronisalieoverhead en complexiteit-overhead. Als cen logisch vervolg zall in de jaren negentig het onderzoek zich stellig concentreren op parallellisme waarin relevante kennisrepresentaties gecombineerd worden met het zoekproces. Daarnaast bestaat er nog een andere trend in de parallelle ontwikkelingen, te weten de neurale netwerken. Daarop komen we in 8.3 nader terug. In figuur 7 presenteren we de vier AI-onderzoeksfasen te zamen met onze toekomstverwachtingen langs een globale tijd-as.

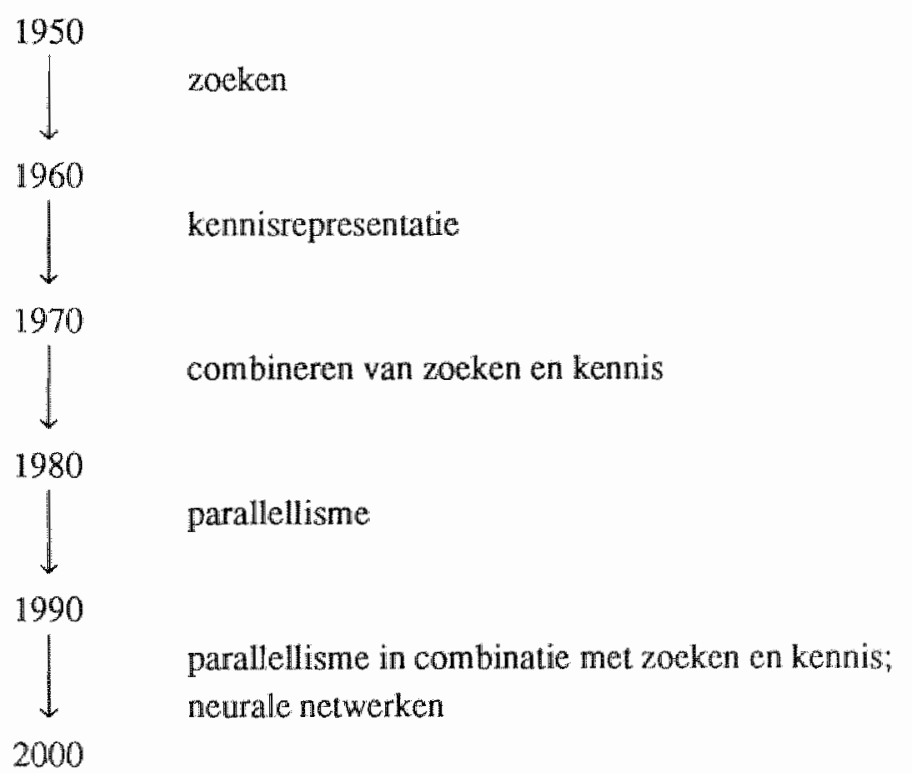

Figuur 7: De fasen in AI-ontwikkelingen. 


\section{SCHAKEN: ONDERZOEKSGEBIED BIJ UTTSTEK}

Het schaakspel begeleidt als een richtsmoer de AI-geschiedenis. Shannon (1950) en Turing (1953) kozen het als onderzoeksgebied voor hun AI-idleeën. Van de 26 Turing-Award-winnaars hebben er vier (McCarthy, Newell, Simon en Thompson) op dit gespecialiseerde informatica-gebied onderzoek gedaan. Toch zie ik dat menige onderzoeksrapporteur, waarschijnlijk niet gehinderd door enige schaakkennis, computerschaak verwijst naar het gebied van AI-passé of op z'n gunstigst er cen kleine of onbetekenende rol aan toekent. In Bree et al."s (1983) onderzoeksrapport $A l$ in the Netherlands werd computerschaak in een enkele zin afgedaan. Ten onrechte, zoals A.D. de Groot in een evenwichtige reactie destijds liet weten. Er zijn meer voorbeelden (zie b.v. Van den Herik. 1988a).

\subsection{Waarom computerschaak?}

Om thet belang ervan aan te geven wijzen we allereerst op de volgende onderzoekscentra waar computerschaak een vooraanstaande rol speelt en die in de informatica-gemeenschap een grote faam hebben: Turing Institute (Glasgow), Carnegie-Mellon University (Pittsburg, Pa.), Bell Laboratories (Murray Hill, N.J.), Lawrence Livermore Laboratory (Livermore, Ca.), Cray Research, Inc. (Los Alamos, N.M.), Los Alamos National Laboratory (Los Alamos, N.M.), University of Alberta (Edmonton, Alberla). (Onlangs werd vanuit Canada op het UNIX Newsnet de University of Limburg ook aan deze reeks toegevoegd.)

Bovendien geven we ter ondersteuning vier meningen van prominente onderzoekers (cf. Van den Herik, 1982a, 1982b).

Shannon: "Als iemand nu eens langs kwam mel een goede manier om de begrippen die grootmeesters hebben er zonder al te veel moeite in te brengen, dan zou dat op vele terreinen nuttig zijn."

Simon: "Het is toepasselijk op leerprocessen, het is toepasselijk op beslissingsprocessen, probleem-oplossingsprocessen. We kunnen onszelf effectiever maken in intellectucle activiteiten."

Marsland: "Ik denk dat de resultaten van computerschaak in bredere zin toepasselijk zijn, maar misschien niet op de manier die we graag zouden zien. De resultaten bijvoorbeeld op het terrein wan de gegevensstructuur, het terrein van kennisrepresentatie, op de terreinen van wat je kunt doen met rauw computervermogen, zouden mensen op andere gebieden vertrouwen geven."

Michie: "De toepasbaarheid is, denk ik, geweldig en totaal kritisch. De wetenschappelijke bestudering van computerschaak, wat natuurlijk het technologische werk inhoudt, maar er ver bovenuit gaat, is de belangrijkste wetenschappelijke studie die zich nu in de wereld afspeelt."

Overigens moet toch, hoe gewichtig bovengenoemde opsomming en citaten ook zijn, worden verwezen naar Dreyfus (1980), eerder genoemd in paragraaf 3.2, die het belang van schaken als microwereld in isolatie wel erkent, maar toepassingen 
op andere gebieden nagenoeg uitsluit. En eerlijkheidshalve dient daatbij opgemerkt te worden dat hij ook medestanders heeft.

Daarom wil ik enige woorbeelden noemen van resultaten, begrippen en ideeün die via het computerschaak beschikbaar zijn gekomen; het hoofdstuk sluit ik af met cen overzicht van het machineschaak (figuur 8 ) en een historisch overzicht van het computerschaak (figuur 9), waarin men de diverse ontwikkellingen kan vollgen zoals die in de voorafgaande hoofdstukken zijn geschetst.

\subsection{De verdiensten van computerschaak}

In de periode 1950-1960 zijn veel zoektechnieken ontwikkeld (b.v. het bepalen van de zetvolgorde leidend tot ideeën over best-first search). Daarbij speelden evaluariefuncties een belangrijke rol. In de jaren zestig werden datastructuren ontwikkeld voor kennisrepresentatie, ofschoon het Van der Poel in 1953 reeds gelukt was noties als verdediging, terreinwinst, tempowinst, oppositie, etc. in het KRK-eindspel te implementeren (Van den Herik, 1983). Het 'common-subtree problem' werd in de jaren tachtig opgelost door de invoering van transpositietabellen, een techniek die spoedig in andere gebieden werd overgenomen. Onlangs is deze techniek in de vorm van search tables (Warnock en Wendroff, 1988) geschikt gemaakt voor het mede bepalen van de te volgen strategic.

Daarnaast is het voor bepaalde eindspelen gelukt om volledige kennis van een ultra-complex domein te verkrijgen en op te slatn in databases (Thompson, 1986; Dekker et al., 1987; Van den Herik et al., 1987). Het produceren van ruwe data in databases heeft een nieuwe impuls gegeven aan machine-learning techrieken, die in de loop van de geschiedenis reeds gedomineerd waren door schaken en dammen (Samuel, 1959, 1967; Quinlan, 1979).

Als laatste vermeld ik de bijdragen van De Groot (1946) met zijn hardopdenkprotocollen, welke techniek overgenomen is door Newell en Simon (1972). $\mathrm{Bij}$ de huidige vormen van kennisverwerving is dit nog steeds een veel gebruikte methode.

\begin{tabular}{|l|c|l|}
\hline won Kempelen & 1769 & de Turk (het begin van computerschaak) \\
Babbage & \pm 1825 & Analytical Engine gebruikt voor schaken \\
Torres y Quevedo & \pm 1890 & KRK-machine \\
Zermelo & 1912 & in schaakstellingen bestaat cen beste zet \\
König, Euwe & 1927,1929 & spelregels en eindigheid \\
von Neumann & 1928 & minimax-algorime \\
Zuse & \pm 1934 & eerste relais automaat schaken als \\
& 1944 & toepassing \\
won Neumann & speltheorie \\
en Morgenstem & 1946 & het denken van den schaker \\
De Groot & 1948 & heuristieken \\
Wiener & 1949 & voorloper van Shannon en Turing \\
Nemes &
\end{tabular}

Figuur 8: Historisch overzicht van het machineschaak. 




Figuur 9: Historisch overzicht van het computerschaak.

* Aan de TU Delft hebben meegewerkt aan genoemde successen: H.J. van den Herik (leiding), R.J.C. Bakker, S.T. Dekker, I.S. Herschberg, R.W.G. Hünen en N. Nakad.

** Aan Carnegie-Mellon University hebben meegewerkt aan genoemde successen: H.J. Berliner (leiding), M. Campbell, C. Ebeling, G. Goetsch, L. Slomer en A. Palay. 


\section{ONTWIKKELINGEN EN TOEKOMST}

In de voorgaande hoofdstukken hebben we drie onderdelen van de informatica (hoofastuk 2) bezien en daarbij de nadruk gelegd op Al (hoofdstukken 3 tot en met 7). Hieronder willen we de samenhang van de diverse onderdelen nader beschouwen, alsmede hun betrokkingen met andere disciplines, zoals psychologie on filosonie.

\subsection{De samenhang tussen Al en informatiesystemen}

Het ontwerpen van informatiesystemen kan opgevat worden als een bijzonder geval van een proces van probleemoplossen (Sol, 1984). In zijn inaugurele rede toonde Sol (1984, pp. 6-11) de tot dan toe bekende samenhang tussen de verschillende fasen van een informatiesysteem. Het centrale thema was toen in fette cen combinatie van numerieke algoritmen (cf. 2.1) en gegevenswertamelingen (cf. 2.2). Later is daar het onderdeel intelligente handelingen (cf. 2.3) bijgekomen, zodat ik de in Sol (1984, p. 4) gegeven tabel 2 nu kan uitbreiden met een kolom ES (expertsystemen) (zie figuur 10).

\begin{tabular}{|c|c|c|c|c|}
\hline FASE & $\mathrm{GGV}$ & MIS & BOS & ES \\
\hline apparatuur & $\begin{array}{l}\text { centraal } \\
\text { batch }\end{array}$ & $\begin{array}{l}\text { centraal } \\
\text { on-line }\end{array}$ & $\begin{array}{l}\text { decentraal, } \\
\text { personal } \\
\text { computing }\end{array}$ & \\
\hline $\begin{array}{l}\text { soort } \\
\text { problemen }\end{array}$ & processen & $\begin{array}{l}\text { informatie- } \\
\text { verzorging }\end{array}$ & $\begin{array}{l}\text { beslissings- } \\
\text { ondersteuning }\end{array}$ & $\begin{array}{l}\text { zellstandige } \\
\text { redenering }\end{array}$ \\
\hline $\begin{array}{l}\text { optiek } \\
\text { (denkwijze) }\end{array}$ & procesgericht & $\begin{array}{l}\text { gegevens- } \\
\text { gericht }\end{array}$ & objectgericht & relatiegericht \\
\hline $\begin{array}{l}\text { modelcyclus } \\
\text { (afbeeldings- } \\
\text { wijze) }\end{array}$ & deductiel & inductief & $\begin{array}{l}\text { hypothetisch- } \\
\text { inductief }\end{array}$ & $\begin{array}{l}\text { heuristisch } \\
\text { recursief }\end{array}$ \\
\hline doelstellingen & $\begin{array}{l}\text { directe } \\
\text { informatie } \\
\text { behoefte }\end{array}$ & verbanden & $\begin{array}{l}\text { indirecte } \\
\text { informatie } \\
\text { behoefte }\end{array}$ & $\begin{array}{l}\text { indirecte } \\
\text { verbanden }\end{array}$ \\
\hline $\begin{array}{l}\text { methodiek } \\
\text { (werkwijze) }\end{array}$ & lineair & iteratief & incrementeel & $\begin{array}{l}\text { heuristisch } \\
\text { incrementeel }\end{array}$ \\
\hline $\begin{array}{l}\text { projectbesturing } \\
\text { (beheerswijze) }\end{array}$ & projectgroep & harmonie & participatief & $\begin{array}{l}\text { participatief, } \\
\text { vervangand } \\
\text { op onderdelen }\end{array}$ \\
\hline
\end{tabular}

Figuur 10, De ontwikkelingsfasen van een informaticsysteem tot een expertsysteem. 


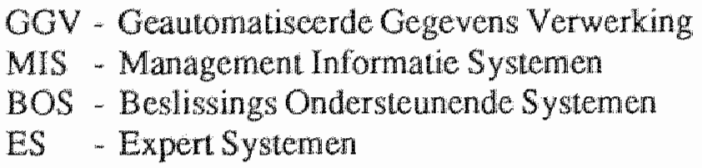

Het lege vak rechtsboven (apparatuur voor ES) is met opzet leeg gelaten, omdat expertsystemen tegenwoordig verwezenlijkt kunnen worden op het gehele bereik, vanaf PC's tot supercomputers. Als we de ontwikkeling van neurale netwerken (zie 8.3) eveneens in ogenschouw nemen dan valt te verdedigen dat de beschrijvingen voor de diverse onderwerpen samenvallen met ES-beschrijvingen, zoals die in hoofdstuk 5 liggen besloten.

Als ondersteuning voor het bouwen van informatiesystemen wordt tegenwoordig vaak een beroep gedaan op CASE-orngevingen (Computer Aided Systems Engineering). De Rijksuniversiteit Limburg onderzoekt als logisch vervolg op deze ontwikkelingen binnen het INCA-project in samenwerking met Westmount Technology (Delft) de mogelijkheden van een INtelligente CAse omgeving. Het uitgangspunt van dit onderzoek, dat onder leiding van P.J. Braspenning (RL) en H.E. Keus (Westmount) staat, is gelegen in het object-georiënteerd modelleren van omgevingen. Daarmee wordt een fundament gelegd voor diverse AIfunctionaliteiten, zoals incrementele planning, redeneertechnieken en leervermogens.

\subsection{Cognitieve simulatie}

Als we, volgens onze eigen definitie en doelstelling (cf. 3.1), een beter inzicht willen verkrijgen in menselijke denkprocessen (een samengaan van implementatie en fundamentele modellering), dan zullen we simulaties van deze processen, hoe dan ook, in een computerprogramma dienen te verwezenlijken. Het oorspronkelijke doel van AI-onderzoekers was overigens heel wat sterker: men wilde begrijpen welke principes ten grondslag liggen aan menselijke intelligentie (cf. Winstons definitie en doelstelling).

Historisch gezien is met het onderzoek naar het (re)produceren van intelligent gedrag een begin gemaakt door McCulloch en Pitts (1943), die zich theoretisch bezighielden met de mogelijkheid intelligent gedrag te imiteren op het niveau van losse neuronen. Ander baanbrekend werk in de beginperiode van de computer is verricht door Ashby (1952). De belangrijkste bijdrage, een theorie over perceptrons, staat op naam van Rosenblatt $(1958,1962)$, hoewel deze theorie beter en in een betere samenhang beschreven is door Minsky en Papert (1969). Van dit laatste boek is in 1988 een uitgebreide herdruk verschenen, die de hernieuwde belangstelling voor dit onderwerp (zie 8.3) duidelijk aangeeft.

Toen in de jaren vijftig, na veel en intensief onderzoek de doelstellingen, het modelleren van een hersenstelsel (van een mens of een regenworm) op grond van neuronale, vaak binaire netwerken, door leidende Al-onderzoekers als te simplistisch werd beschouwd, stapte men over op andere modellen. In plaats van op het laagste fijnkorrelige niveau, het neuron, iets te modelleren was de volgende ambitie te modelleren wat zich op kennis-niveau afspeelt: het modelleren van cog- 
nitieve processen. Meijsing (1986) laat de periode van onderzoek naar fijnkorrelige imitatie in 1966 afsluiten door Rosenblith (1966) als hij opmerkt dat "een fijnkorrelige vergelijking vergeefse moeite is en in feite onbeslisbaar".

Eigenlijk waren de computermodellen bij veel onderzoekers (bijv. Turing, von Neumann en Simon) al eerder verschoven van het fijnste neuronale niveau naar het grofkorrelige niveau, waarvan men hoopte dat het de menselijke gedragsaspecten zou kunnen weergeven. Hiertoe behoorden eveneens de hardop-denkprotocollen in het GPS-onderzoeksprogramma van Newell en Simon (1972). Omstreeks 1959 verliet men evenwel ook de gedachte dat Al-programma's gebaseerd dienden te zijn op menselijke intelligentie (zie figuur 6: Samuels Checkers-programma). Het ging niet langer om het begrijpen van de aard van intelligentie, maar om het oplossen van moeilijke problemen, die als ze door mensen opgelost worden intelligentie vereisen. We zien derhalve dat het grofkorrelige onderzoek gekarakteriseerd wordt door de definitie en de doelstelling van Rich (cf. figuren 2 en 3).

Ofschoon deze black box-benadering een aantal prachtige technieken heeft opgeleverd, zoals Robinsons (1965) resolutie-principe, werd zij door veel AIwerkers toch met een zekere tegenzin geaccepteerd. Zij zagen hun computerprogramma"s liever als middelen die een beter inzicht verschaften in de menselijke denkprocessen. Volgens hen zouden veel redeneertechnieken in AIprogramma's overeenkomen met door mensen gehanteerde technieken (cf. de definitie en doelstelling van Van den Herik in de figuren 2 en 3). De verschuiving naar het middelfijnkorrelige niveau van onderzoek, waarbij weer (enige) nadruk valt op menselijke intelligentie, komt overeen met de overgang zoals die in figuur 6 is aangegeven tussen 1975 en 1979.

Bij de praktische verwezenlijkingen van AI-programma's blijkt dat de aansluiting tussen computerprogranma en menselijke gebruiker niet in alle gevallen op het niveau van kennisrepresentatie of van het redeneren met kennis plaatsvindt. Daarom zijn cr technicken ontwikkeld die de resultaten van een machinc-gericht representeren en redeneren via een vertaalsiag omzetten naar een mens-gerichte presentatie van resultaten (Uiterwijk, 1988a). In de vakgroep informatica van de Rijksuniversiteil Limburg wordt gewerkt aan de verwezenlijking van het programma CANAPE (Conversion between Analytic and Non-Analytic Proofs: the Expert), dat dergelijke omzettingen automatisch kan uitvoeren (Uiterwijk, 1988b).

Hoewel ik tussen 1995 en 2000 opnieuw een verschuiving verwacht, namelijk naar verruimde blikvelden (zie figuur 6) denk ik niettemin dat het cognitieve onderzoek middelfijnkorrelig wan aard zal blijven. Dit zal mijns inziens een hele tijd duren (enkele decennia), maar na verloop van tijd zullen onderzoekers toch weer willen weten welke principes er aan intelligentie ten grondslag liggen en zijn we terug bij Winstons definitie en doelstelling.

\subsection{Neurale netwerken en gedistribueerde verwerking}

In hoofdstuk 2, Informatica, hebben we beschreven dat onderzoekers achtercenvolgens op het idee kwamen om computers te gebruiken voor het omgaan met getallen, data en symbolen (kennis). In 6.4 hebben we betoogd dat parallelle verwer- 
king gebruikt kan worden voor een aanzienlijke snelheidsvergroting. Voorts weten we al sinds 80 jaar of langer dat het menselijk brein voor een deel is opgebouwd uit neurale netwerken, die niet sequentieel maar parallel werken. In 8.2 hebben we de beginperiode van het modelleren van zulke netwerken uiteengezet. Ondanks het feit dat dit beginonderzoek in de jaren vijftig langzaam maar zeker werd verlaten en de meeste geschriften erover zonder wetenschappelijke waarde (Minsky en Papert, 1988, p. 4) waren, heeft de gedachte aan een combinatie van parallelle activiteiten en intelligente kennisbeheerders de onderzoekers nooit losgelaten.

Nu parallelle machines metterdaad beschikbaar zijn is het onderzoek op het grebied van neurale netwerken, waarin massief parallellisme (connectionisme) gebruikt wordt, opnieuw tot bloei gekomen. Minsky en Papert (1988) vragen zich nog wel af wat de eigenlijke reden is dat de connectionisten weer aan bod konden komen tegenover de symbolisten. Is het werkelijk alleen het beschikbaar komen van nieuwe hardware of is het cen culturele heropwelling van het holisme (cf 3.2)?

Het concept van neurale netwerken is heel simpel: het systeem bestaat uit zeer veel eenvoudige processoren - perceptrons genaand, als eerbetoon aan Rosenblatt ", die beslissingen nemen, dat wil zeggen dat ze vaststellen of een gebeurtenis overeenkomt met een bepaald "patroon" en de verkregen informatie toevoegen aan de bestaandle informatie. Perceptrons kunnen communiceren en, afhankelijk van de structuur, zelf bepalen met wie ze communiceren.

Het is misschien wat verrassend, dat neurale netwerken door middel van diverse theoretische kaders binnen de (vaste-stof) fysica zijn te beschrijven (Hopfield, 1982). Er blijkt zelfs een reeks van theoretische formalismen te zijn, die met vrucht gebruikt kunnen worden ter beschrijving van netwerkactiviteit. We noemen hier onder andere de spin-glass-theorie (Gross en Mezard, 1984; Amit et al., 1985; Kirkpatrick en Toulouse, 1985), de reacrie-diffusie-theorie (Steels, 1988) en het gebruik van statistische mechanica (Toulouse et al., 1986). De effectiviteit. van deze architecturen kan worden getoetst aan het toepassingsgebied, waarvan de drie belangrijkste op dit moment zijn: data-analyse, patroonherkenning en besturingssystemen (Manuel, 1988). Aan de Rijksuniversiteit Limburg zijn plannen ontwikkeld (en ingediend) om neurale netwerken te beschrijven vanuit een nog niet eerder geprobeerd, maar waarschijnlijk vruchtbaar theoretisch kader als de meervoudige-verstrooiingstheorie (Braspenning, 1982; Braspenning et al., 1984; Stefanou et al., 1987). Dit eveneens aan de (vaste-stof) fysica ontleende theoretische kader zou de netwerkactiviteit niet zozeer als een verzameling van gekoppelde niet-lineaire differentiaalvergelijkingen beschrijven, maar veeleer als een verzameling van integraalvergelijkingen die in matrixvorm gebracht kunnen worden. Ook dit theoretische kader laat toe dat in de uitwoer van iedere netwerkeenheid informatie overgedragen wordt over alle vormen van invoer. De RL zal daarnaast een atantal architecturen op hun verdiensten onderzoeken voor de vingerafdruk-herkenning en voor het bepalen van het juiste plan in schaakeindspelen (neurale schaakmachine). De vakgroep beschikt reeds over de Rochester Simulator voor neurale netwerken.

De effecten van gedistribueerde samenwerking tussen intelligente kennisbeheerders, die een aanzienlijk complexere activiteit vertonen dan artificiële neuronen, 
worden binnen de vakgroep informatica nader onderzocht in de projecten IKAROS (Interactive Knowledge Agencies Relating their Organizational Stance) en DAEDALOS (Distributed Agents Evolving into Data Actors within a Loosely Organized Society). Deze projecten, die uitgevoerd worden met ondersteuning van IBM Nederland, berusten in beginsel op gedistribueerde architechuren.

IKAROS, onder leiding van P.J. Braspenning, is gerich op de vraag hoeveel iedere kennisbeheerder moet weten van zijn organisatorische positic binnen het probleemoplossingsproces om daaraan cooperatief mee te werken. Geavanceerde redeneermethoden worden op hun brukbaarheid onderzocht (Braspenning, 1986, 1987; Mulder en Braspenning, 1988).

DAEDALOS, onder leiding van H.J. van den Herik, is gericht op de vragg welke data-fusie-schema" $\$$ voor ongelijksoortige data haalbar en efficient zijn. Ook efficiente fusie-schema's zullen naar verwachting gebruik moeten maken van geavanceerde redeneerschema's ten aanzien van de beschikbare hulpbronnen. Het NCube/4+ project vormt een goede uitgangspositie voor het DAEDALOS-project (Henseler et al., 1987, 1988).

Bij zulk onderzoek resteert, wanuit de AI gezien, nog allijd de vraag of een (neuronaal) newerk kan dienen als model voor de hersenen. Minsky en Papert (1988, p. xiv) geven daar een duidelijk antwoord op: "Nee, ieder gerealiseerd homogeen netwerk kan niet dienen als model voor ons brein, masr als we zulke netwerken als mogelijk model voor een gedeelte van onze hersenen beschouwen dan zullen de twee verkregen overzichten elkaar aanvullen".

En inderdaad, de integratie van klassieke kennissystemen met neurale netwerken zal zeker een thema van groot belang worden. De Rijksuniversiteit Limburg wil daarbij het voortouw nemen vanuit de gedachte, clat altijd al denken (ais bewuste activiteit) en perceptie (als onbewuste, moeilijk locaal representeerbare activiteit) onderscheiden zijn, maar meestal niet gescheiden zijn.

\subsection{Filosofische discussies}

Tot slot will ik kort stilstaan bij de filosofische discussies die zich rondom en binneri de $A l$ hebben afgespeeld. Ik heb niet de pretentie enige fundamentele bijdrage te leveren, maar beschouw het onderwerp Informatica en het menselijk blikveld als onvolledig behandeld indien niet tenminste cen overzicht gegeven word van de belangrijkste filosofische stromingen die zich beziggehouden heb. ben met Al.

Het is moeilijk, zo niet onmogelijk, uit te maken of de psychologie dan wel de fillosofie de voorhand heeft gehad in de beschouwingen over computers. Wel is het opmerkelijk dat de stromingen binnen de psychologie (met als studie-object de aard van intelligentie) minder direct aansluiten bij de ontwikkelingen binnen de informatica dan de filosofische stromingen. We kunnen daarbij denken aan het korrel-probleem uit 8.2 .

Voorts zouden we ons kunnen arvragen hoe relevant het is om een zuiver computer-theoreticus als Turing te confronteren met het behaviorisme, of om de filosofische plaats te bepalen wan (de ideeèn wan) von Neumann. 
Welnu, we kunnen gerust stellen dat eigenlijk alle Al-ondenoekers bij hun idesenontwikkcling over het mechanische denken (Shannon, 1950) vroeg of laat oplopen tegen het meest fundamentele probleem, het lichaan-geest-probleem, waarvan de filosofische wortes liggen in het dualisme van Descartes. (Anderson, 1964, Haugeland, 1981).

Turings (1950) artikel, warin het imitatie-spel (nu algemeen Turing-test genoemd) wordt geintroduceerd, heeft een benadering die aansluit bij het behaviorisme (Skinner, 1953). Turing beweert in essentie dat aan een systeem dat de Turing-test succesvol doorstaat ongereserveerd menselijk denken kan worden toegeschreven. Lucas (1961) denkt evenwel dat hij een a priori reden kan aanvoeren tegen ieder toeschrijwen van menselijk denken aan een computer. Hij meent daarbij aan te kunnen tonen dat de onvolledigheidsstelling van Gödel deze reden ondersteunt: Lucas gebruikt in zijn betoog het begrip Turing-machine (Turing, 1936) uitvoerig, maar gaat niet in op de Turing-test. De discussie is nog steeds niet definitief afgesloten, maar Lucas' positie heeft inmiddels veel tegenstand ondervonden (DeLong, 1970).

Gerulime tijd spitst de discussie zich in de jaren zestig dan toe op de vraag in hoeverre het filosofisch reductionistische programma door de ideeënontwikkeling over het mechanisch denken meer praktische toepasbaarheid kan krijgen (Nagel, 1961). Aanhangers van het filosofisch reductionisme betogen dat de wetten van wetenschappen die zich op een "hoger niveau" van abstractie bewegen, zoals psychologie en sociologie, reduceerbaar zijn tot wetten van wetenschappen die zich met een "lager niveau" van abstractie bezighouden, zoals biologie, scheikunde en elementaire-deeltjes fysica. Van AI-zijde wordt in deze fillosofische discussie bijgedragen door te trachten de werking van een intelligent programma te verklaren met louter aanmamen en theorieedn over neuronen en neuronalle netwerken. Putnam (1973) analyseert de argumenten van de reductionisten diepgaand en komt tot de conclusie dat hun opvattingen onjuist zijn.

Vervolgens wordt de complexiteit van intelligent gedrag van programma's door het functionalisme in een brede context geplaatst. Het essentiele kenmerk van een mentale toestand is volgens hen gelegen in een verzameling van causale relaties die betrekking hebben op de omgeving, op andere typen mentale toestanden en op het gedrag (Churchland, 1984; Fodor, 1975). Pylyshyn (1984) gaat verder op zoek naar eigenschappen van de functionele architecturen. Hij komt terecht bij functies in een programma, dat wil zeggen in computationele processen, die als primitieve eenheid opgevat dienen te worden. Hiermee wordt de basis gelegd voor de volgende stap in de ontwikkeling van ons denken over denken, namelijk de com putavionele psychologie. In deze stroming probeert men vast te stellen wat het mentale programma is en het menselijk handelen te verklaren in termen van regels on representatio.

Ook in de jaren tachig gaat de fundamentele filosofische discussie of menselijk denken aan een computer kan worden toegeschreven onverminderd voort. De sterke AI - een term die ingevoerd is door Searle (1980) - betoogt dat als een systeem $\mathrm{S}$ de Turing-test passeert er mentale eigenschappen aan het systeem toegeschreven mogen worden. In de huidige discussies wordt met betrekking tot naturlijke taal het sterke AI-standpunt verdedigd door Schank (1979). 
Searle (1984) heeft als tegenstander van de sterke AI getracht om een a priori argument te geven tegen de genoemde gevolgtrekkingen van het succesvol doorstaan van de Turing-test, zelfs als dit slagen voor de Turing-test op een beperkt gebied gebeurt, zoals het begrijpen van natuurlijke taal. Searle's (1984) vastberaden poging om de sterke AI af te wijzen berust op een gedachte-experiment - het Chinese kamerprobleem - waarbij Searle tot de conclusie komt dat er nooit mentale eigenschappen aan een computerprogramma toegekend kunnen worden, ook niet als het de Turing-test passeert. Dit gedachte-experiment heeft tot uitvoerige discussies geleid waarbij voor-en tegenstanders uiteindelijk toch weer filosofische intuïties in het geding brengen, die het gedachte-experiment nu juist beoogde uit te sluiten (Doorman, 1989).

Tegenover de sterke AI definieert Searle (1980) de zwakke Al: een computerprogramma is cen verhelderende metafoor voor het menselijk denkproces, de 'gewone' gevolgtrekkingen van de sterke AI over het passeren van de Turing-test worden overgenomen (namelijk zonder dat mentale eigenschappen aan het programma worden toegeschreven). Overzien we het veld van filosofische stromingen dan kan de zwakke AI, ongeacht de uitkomst van het filosolische debat, erop bogen een bijdrage geleverd te hebben aan de voor filosofen en psychologen zo belangrijke vraag: hoe zit het menselijke denkproces in elkaar?

\section{CONCLUSIES EN TOEKOMSTVERWACHTINGEN}

\section{Conclusies}

Gekomen aan het eind van mijn beschouwing bied ik u nog eenmaal een aantal van mijn conclusies aan.

- Heuristieken, zoals die zonder de computer niet hadden kunnen worden ontwikkeld, zijn ruwe hulpmiddelen, geenszins zekere gidsen tot de beste oplossing(en).

- Kennis van cen terrein, hoe menselijk ook voor mensen, blijkt vaak mocilijk te vatten in programma's: als het programma "weet" dat iets het beste is, is dit voor een mens, die de aanbeveling opvolgt, vaak in eerste instantie onbegrijpelijk.

- Computerschaak is niet alleen een voortreffelijk proefterrein voor Al, het kan er ook op bogen een grote bijdrage geleverd te hebben aan de verrijking van onze kennis, doordat computerschaakonderzoek als eerste en enige van de algoritmische benaderingen, een perfecte speel wijze heeft kunnen aangeven voor menig altra-complex (eindspel)domein. Dat niet elke menselijke speler de zin (of strategische bedoeling) van de beste zet kan begrijpen, is een tckortkoming. Deze tekortkoming mag echter niet aan het computerprogramma geweten worden, maar ligt helaas verankerd in de inherente complexiteit van het gekozen domein. 


\section{Toekomstverwachtingen}

Voortbordurend op de conclusies en gebruikmakend van mijn eigen onderzoekservaringen formuleer ik hieronder vier toekomstverwachtingen: ến voor de korte termijn (1990), twee voor de middellange termijn (1995-2000; 2000-2020) en ến voor de zeer lange termijn (over enkele eeuwen).

1. Op dit ogenblik is elke positieve verwachting van AI onlosmakelijk verbonden aan het parallellisme. Talloze experimenten bevestigen de veronderstelling dat sequentiële verwerking effectief zou kunnen worden ondersteund door parallelle verwerking op machines die, elk voor zich genomen, geen grotere verwerkingscapaciteit hebben.

2. Langzaam maar zeker worden machines intelligent. Ik wil in deze oratie graag afzien van een exacte definitie van het begrip intelligentie, maar wel wil ik vaststellen dat zelfs heden ten dage een gebruiker zich beter begrepen voelt dan enkele jaren gelleden.

3. Op grond van mijn eigen onderzoek en dat van, bijvoorbeeld, Ken Thompson kan ik niet anders dan tot de conclusie komen dat binnen niet al te lange tijd, zeg in de eerste 20 jaren van de volgende eeuw, een computer (maar dat wil zeggen alle computers) sterker zal zijn dan de dan regerende menselijke wereldkampioen schaken.

4. Ten slotte, maar nu word ik wel erg speculatief, schat ik dat onze huidige theorieën over het menselijk denken, zoals het nabootsbaar zijn op computers, nog decennia op het huidige peil zullen blijven, maar dat veel later, misschien vele honderden jaren later, de functies van onze hersenen tot op het neuron zullen worden nagebootst.

\section{WOORDEN VAN ERKENTELIJKHEID}

Mijn dank gatat uit naar het College van Bestuur dat mij benoemd heeft tot gewoon hoogleraar in de informatica en mij daarmee in de gelegenheid heeft gesteld het onderzoek aan de Rijksuniversiteit Limburg tot speerpunt-onderzoek te maken binnen de Al-gemeenschap. Voorts ben ik het College erkentelijk voor het ter beschikking stellen van een werkdag voor wetenschappelijke ontplooiing buitenshuis en voor de toestemming om deze dag te besteden aan een bijzonder hoogleraarschap aan de Rijksuniversiteit Leiden in de Faculteit der Rechtsgeleerdheid.

In de korte tijd die ik tot dusver hier in Maastricht aan de Rijksuniversiteit Limburg heb mogen doorbrengen heb ik ruimschoots gelegenheid gehad voor mijn staf grote waardering op te vatten. I $k$ ben ervan overtuigd dat deze waardering in de loop van de tijd stellig zal toenemen, al "groeien wij vast in tal en last' 1 .

1) Zie voetnoot op de volgende bladzijde. 
Mijn studenten, aio's en promovendi, de tegenwoordige en de vele toekomstige die hen, hoop ik, zullen aflossen wil ik nadrukkelijk op het hart binden dat ik me van tijd tot tijd een moeilijk leermeester zal tonen, die jullie op een onbekend en zelfs onverkend pad zal zetten. Jullic wanhoop wordt, hoop ik, daarbij watt getemperd door het feit dat ik beloof met jullie mee te trekken en waar mogelijk voorop te lopen waar de doornen hat stekeligst zijn.

Ik besluit, nalar het gebruik der voorgangers, met enkele woorden die zich richten tot hen die mij geschoold en gevormd hebben.

\section{Hooggeleerde Herschberg!}

De laatste acht jaar ben je mijn mentor geweest op vrijwel elk terrein waarop ik me in wetenschappelijke zin bewogen heb. Of het nu ging over subtiele methodologische punten in mijn proefschrtift of over details in do formulering van artikelen voor de ICCA Journal, ik heb nooit tevergeefs een beroep op je tijd of uithoudingsvermogen gedaan en de hoeveelheid rode kleurstof uit je venijnige correctiepennetje wordt zcker in vele tientallen kilometers gemeten. Je constructieve kritiek was me nuttig en welkom en zal datt, hoop ik, nog lang blijven.

\section{Hooggeleerde De Groot!}

Als geen ander heb je de analyse van het denken van de schaker al sinds je eigen promotie in 1946 bevorderd. Ik ben er trots op je voetsporen gevolgd te hebben, zij het dat mijn blikveld door computers bepaald wordt. Mij past dankbaarheid jegens jou, met name voor je bereidwilligheid om je als promotor in zo een andere Weltanschauung te verplaatsen.

\section{Hooggeleerde Doorman?}

Ook jou mag ik als promotor toespreken. Onze samenwerking heeft zich echter niet beperkt tot die tussen promotor en promovendus: zonder uitputtend te zijn herimner ik me met passende dankbaarheid onze Al-colloquia in Delf, watar ik, de doener, en jij, de denker, elkaar aanvulden, al ging dat niet altijd zonder strijd, maar: du choc des opinions jaillit la vérité?

\section{Hooggeleerde Lombaers".}

Promotor en practicus bij uitstek: in deze frase zou ik met gepaste erkentelijkheid jouw bijdrage willen samenvatten. Je hebt me aangezet, ja zells geprikkeld, tot

1) Narr Vondels $(1634 ?)$ :

OP ONS WETSHUIS:

Wij groeien vast,

In talal en last,

Ons tweede vaders klagen.

Ai. ga niet woon,

Door deze poon,

Of help een lutel dragen 
onderzoek van het computerschaak; in het kort gezegd door me de handschoen toe te werpen waarop als het ware in grote letters geschreven stond: Later we maar eens kijken of het werkt.

\section{Hooggeleerde Euwe!}

Helaas ben je niet meer in het land der levenden. Toch wil ik over deze grote grens heen van mijn dankbaarheid getuigen: was jij het niet die in de eerste dagen, toen doenlijkheid en wettigheid van computerschaak nog bevochten moesten worden, je met je grote reputatie in gemeenschappelijke lezingen inzette voor wat nu gelukkig blijkt niet alleen een goede, maar ook een aanvaarde zaak te zijn?

\section{Hooggewaardeerde Thompson!}

Het is maar zelden dat we van een winnaar van een Turing Award zo weinig in druk hebben zien verschijnen. Ik ben dankbaar en trots dat veel van wat uit jouw baanbrekend werk het publiek bereikt heeft, met graagte en zonder voorbehoud afgestaan is aan de ICCA Journal, waar het een grote stimulans was voor uitwerking en verfijning door anderen en mijzelf.

\section{Hooggeleerde Kaashoek!}

Het zou van ondankbaarheid getuigen als ik je niet hier en nu memoreerde. Immers, met een kleine variant, in ons heden ligt het verleden en jij was het die al tijdens mijn studie aan de Vrije Universiteit me aanspoorde het juiste evenwicht te bewaren tussen schaken en wiskunde en het eén te doen zonder het ander te laten.

\section{Hooggeschatte Ten Kate!}

Voor het eerst van mijn leven waag ik het $U$ te tutoyeren, om je, nu niet meer in statu pupillari, te danken voor het rechte spoor waarin je me met zachte maar besliste dwang hebt gehouden. Zonder je tussenkomst had ik me verslingerd aan het schaken; dankzij jouw vaste hand als rector heb ik het einddiploma aan het Marnix-Gymnasium in Rotterdam behaald. Misschien doet het je genoegen te horen dat ik daarvan nu een der curatoren ben.

\section{Welledelgeleerde Kooi!}

Aan je milde uiterlijk kan niemand die jou niet kent de verwoedheid aflezen waarmee je mijn stappen gevolgd hebt. Kritisch meelezen bij het totstandkomen van een dissertatie, scherp letten op elke letter die sindsdien in het openbaar uit mijn pen gevloeid is, - het waren en zijn je wezenskenmerken. Dit vooral wil ik in herinnering roepen: je gaf je kritiek zonder hoop op beloning, zelfs niet in de hoop op een eervolle vermelding die ik je bij deze dan ook voor het eerst, in dank, kan laten geworden.

\section{Lieve Letty Raaphorst!}

\section{Lieve Seada, Larissa en Kirsten van den Herik!}

Ik wil jullie, verschillend van naam maar toch zo intens met mij en elkaar verbonden, op deze dag uitdrukkelijk noemen. Ik ben er de man niet naar om het dagelijks te zeggen en jullie zijn er de vrouwen niet naar om dat te eisen, maar ik besef terdege dat ik jullie door alle activiteiten die me tot katheder en toga hebben 
geleid tekort gedaan heb. Vaak was ik er niet, soms was ik er wel maar verkeerde, zoals dat heet in hoger sferen, concreter gezegd: op mijn studeerkamer, op zolder. Hoe dan ook, wees er met z'n vieren van overtuigd dat jullie hebben bijgedragen aan mijn enthousiasme. Ik ben dankbaar voor alle ondersteuning, die ik zo vaak spontaan en vol begrip van jullie heb gekregen.

\section{Lieve Onders!}

'Is', roept de profeet Jeremia (31: 20) uit, 'Efraim Mij niet een geliefde zoon, een zoon in wie ik vreugde schep". Als zoon Efraìm, gekoesterd, geprikkeld tot kennis en tot groei in wijsheid heb ik me in jullie handen gevoeld. Mag ik vanaf deze plaats die ook voor jullie in afgeleide zin een kroon op het werk moet zijn, jullie danken; mag ik ons drieen gelukkig prijzen met het feit dat het ons gezamenlijk gegeven is deze dag met elkaar te mogen beleven.

\section{REFERENTIES}

Amit, D.J., Gutreund, H., and Sompolinsky, H. (1985). Spin-glass models of neural networks. Phys. Review A, Vol. 32 (2), pp. 1007-1017.

Anderson, A.R. (ed.) (1964). Minds and Machines. Prentice-Hall, Inc., Englewood Clifls, N.J.

Arden, B.W. (ed.) (1980). What Can Be Automated? The Computer Science and Engineering Research Sudy (COSERS). The MIT Press, Cambridge, Massachusetts, and London, England.

Ashby, W.R. (1952). Design for a Brain. Willey, New York.

Ashenhurst, R.L. and Graham, S. (eds.) (1987). ACM Turing Award Lectures, The First Twenry Years 1966-1985. ACM Press Anthology Series, New York; Ad. dison-Wesley Publishing Company, Reading, Mass.

Bachman, C.W. (1973). The Programmer as Navigator. ACM Turing Award LeC. tures, The First Twenty Years 1966-1985 (eds. R.L. Ashenhurst and S. Graham) (1987), pp. 270-285, ACM Press Anthology Series, New York; Addison-Wesley Publishing Company, Reading, Mass.

Bal, HE. and Renesse, R. van (1986). A Summary of Parallel Alpha-Beta Search Results. ICCA Journal, Vol. 9, No. 3, pp. 146 149.

Bar-Hillel, Y. (1960). The Present Status of Automatic Translation of Languages. Advances in Computers (ed. F. L. All), Vol. 1, pp. 91-163, Academic Press, New York.

Barr, A. and Feigenbaum, E.A. (1981). The Handbook of Arificial Mulligence. Volume 1. Pitman Books Limited, London. 
Barr, A. and Feigenbaum E.A. (1982). The Handbook of Artificial Intelligence. Volume 2. Pitman Books Limited, London.

Braspenning, P.J. (1982). A Multiple Scattering Treatment of Dilute Metal Alloys: self-consistent muffin-tin impurity potentials, local electron densities of states and cluster-model de Haas-van Alphen relaxation times. Ph.D. Thesis, Free University, Amsterdam.

Braspenning; P.J., Zeller, R., Lodder, A. and Dederichs, P.H. (1984). Seliconsistent Cluster Calculations with Correct Embedding for 3d-, 4d- and some sp-Impurities in Copper. Phys. Review B, 29, p. 703.

Braspenning, P.J. (1986). Reasoning for Interpreting Sensor Data. Proc. Comf. Intelligent Autonomous Systems (eds. L.O. Hertzberger and F.C.A. Groen), pp. 120, Amsterdam

Braspenning, P.J. (1987). Ervaringen met de Multiple Expert Architecture (MXA) omgeving bij het op expliciete kennis gebaseerde probleem oplossen met behulp wan een blackboard systeem. Memo Seat, Nr. 597. Hollandse Signaalapparaten B.V., Hengelo.

Brée, D.S., Kempen, G., Riet, R.P. van de, Wielinga, B.J. en Klint, P. (1983), Artificial Intelligence in the Netherlands. Presented to the Dutch Ministry of Education and Science by the Advisory Committee on Artificial Intelligence.

Churchland, P.M. (1984). Marter and Consciousness. The MIT Press, Cambridge, Mass.

Cohen, P.R. and Feigenbaum, E.A. (1982). The Handbook of Artificial Intelligence. Volume 3. Pitman Books Limited, London.

Dekker, L. (1985). Expandability of a MMD multiprocessor to a large size. Proceedings of the SCS, Eastern Simulation Conference, Norfolk, USA.

Dekker, S.T., Herik, H.J. van den and Herschberg, I.S. (1987). Complexity Starts at Five. ICCA Journal, vol. 10, No. 3, pp. 125-138.

DeLong, H. (1970). A Profile of Marhematical Logic. Addison-Wesley Publishing Company, Reading, Mass.

Doorman, S.J. (1989). Methodologische opmerkingen over een gedachte-experiment. Te verschijnen in Kennis en Methoden.

Dreyfus, H.L. (1972). What Computers Can't Do; A Critique of Artificial Reason. Harper and Row, Publishers, New York-Evanston-San Francisco-London.

Dreyfus, H.L. (1980). Why Computers Can't Be Intelligent. Creative Computimg. Vol. 6, No. 3, pp. 72-78. 
Findler, N.. V. and Meltzer, B. (eds.) (1971). Arifficial Intelligence and Heuristic Programming. Edinburgh University Press, Edinburgh.

Fodor, J.A. (1975). The Language of Thought. Thomas Y. Crowell, New York.

Groot, A.D. de (1946). Het Denken van den Schaker, een experimenteelpsychologische Studie. Proefschrift, Universiteit van Amsterdam; N.V. Noord-Hollandse Uitgevers Maatschappij, Amsterdam.

Gross, D.J. and Mezard, M. (1984). The simplest spin glass, Nucl. Phys. FS B240, pp. $431-452$.

Haugeland, J. (ed.) (1981). Mind Design, Philosophy, Psychology, Artificial Intelligence. The MTT Press, Cambridge, Mass.

Henseler, J., Scholtes, J.C. and Verhoest, C.R.J. (1987). A Parallel Knowledgebased Optical Character Recognition System. Afstudeerverslag TU Delft, Faculteit Technische Wiskunde en Informatica.

Henseler, J., Herik, H.J. van den, Kerckhoffs, E.J.H., Koppelaar, H., Scholtes, J.C. and Verhoest, C.R.J. (1988). Knowledge-based Parallelism in Opticall Character Recognition. Proceedings of the 1988 Summer Computer Simulation Conference (eds. C.C. Barneth and W.M. Holmes), pp. 14-20, The Society for Computer Simulation International, Seattle, USA.

Herik, H... van den (1982a). Interviews, klasse 5 : grondleggers van ideeën. Intern rapport, Onderafdeling der Wiskunde en Informatica, TH Delft, Delft.

Herik, H.J. van den (1982b). Interviews, klasse 6: schaakprogrammeurs. Intern rapport, Onderafdeling der Wiskunde en Informatica, TH Delft, Delft.

Herik, H.J. van den (1983). Computerschaak, Schaakwereld en Kunstmatige Intelligentie. Proefschrift TH Delft, Academic Service, "s-Gravenhage.

Herik, H.J. wan den (1984). Inleiding Artificial Intelligence Technieken. Collegedictaat Technische Universiteit Delft.

Herik, H.J. van den (1985). Heuristicken en Beslissingen. Operations Ressearch, praktijk en theorie (ed. W. Heins), pp. 42-55. Delft University Press, Delft.

Herik, H.J. van den, Herschberg, I.S. and Nakad, N. (1987). A Six-Men-Endgame Database. IC CA Journal, Vol. 10, No. 4, pp. 163-180.

Herik, H.J. van den (1988a). Restitutio Retrospectativi. NVKI Nieuwsbrief, Jrg. 5, Nos. $2 / 3$, pp. $12-15$.

Herik, H.J. van den (1988b). Supercomputers en Artilicial Intelligence. Geavan ceerde computerfaciliteiten voor het technisch en wetenschappelijk onderzoek en 
onderwijs in Nederland. Ad Hoc Werkgroep Investeringen Supercomputers (WIS), SURF 88 1587. Bijlagen A2, pp. 45-47.

Hofland, A. (1987). De HYDRA-Systemen. Afstudeerverslag TU Delft, Faculteit Technische Wiskunde en Informatica.

Hofstadter, D.R. (1979). Gódel, Escher, Bach: an Eternal Golden Braid. The Harvester Press Limited. Hassocks, Sussex.

Hopfield, J.J. (1982). Neural networks and physical systems with emergent collective computational abilities. Proc. Natl. Acad. Sci., USA 79, pp. 2554-2558.

Hyatt, R.M. (1985). Parallel Chess on the Cray X-MP/48. ICCA Journal, Vol. 8, No. 2, pp. $90-99$.

Jeremia $(31: 20)$. De tekst in de Statenvertaling luidt: Is niet Efraïm Mij een dierbare zoon, is hij $M$ ij nilet een troetelkind?; na lange overwegingen heb ik besloten een gezamenlijke vertaling van drs. G.H. van der Bom en dr. I.S. Herschberg als geciteerde vertaling te nemen omdat deze de oorspronkelijke tekst en bedoeling het meest nabijkomt.

Kirkpatrick, S. and Toulouse, G. (1985). Configuration space analysis of travelling salesman problems. J. Physique 46, pp. 1277-1292.

Lucas, J.R. (1961). Minds, Machines, and Gödel. Philosophy, 36, pp. 120-124. Reprinted in Minds and Machines (ed. A.R. Andersson) (1964), Prentice-Hall Englewood Clifs, N.J., and in The Modeling of Mind: Computers and Intel. ligence (eds. K.M. Sayre and F.J. Crosson) (1963), Simon and Schuster, New York.

Mandelbrot, B.B. (1983). The fractat geometry of mature. W.H. Freeman and Company, San Francisco.

Manuel. T. (1988). Are Artificial Neural Networks finally Ready for the Market? Electronics, August, pp. 85-88.

Mars, N.J.I. (1987). Onderzoek van niweau; Kenwistechnologie in wording. Inaugurele Rede, Universiteit Twente. Ook in Informatie, Jrg. 30, No. 2, pp. 84-90.

Marsland, T.A. and Popowich, F. (1985). Parallel Game-Tree Search. IEEE Trans. on Pattern Anal. and Mach. Intell. PAMT-7 (4), pp. 442-452.

McCarthy, J. (1987). Generality in Artificial Intelligence. Communications of the ACM, Vol. 30, No. 12, pp. 1030-1035. Also in ACM Turing Award Lectures, The First Twenty Years 1966-1985 (eds. R.L. Ashenhurst and S. Graham) (1987), pp. 257-267, ACM Press Anthology Series, New York; Addison-Wesley Publishing Company, Reading, Mass. 
MoCulloch, W.S. and Pitts, W. (1943). A Logical Calculus of the Ideas Immanent in Neural Nets. Bulletin of Mathematical Biophysics, Vol. 5, pp. 115-137.

Meijsing, M. (1986). Geest, hersenen, computer. Geest, computer, kunst (eds. P. Hagoort en R. Maessen), pp. 64-88. Stichting Grafiet, Utrecht.

Michie, D. (1982). Information and Complexity in Chess. Advances in Computer Chess 3 (ed. M.R.B. Clarke), pp. 139-143, Pergamon Press, Oxford-New YorkToronto-Sydney-Paris-Frankfurt. De titel van een lezing met dezellde inhoud luidde: Turning a chess description thto a concept-expression (10 april 1981), Imperial College, London.

Michic, D. (1987). Current Developments in Expert Systems. Applicationis of Expert Sytems (ed. J.R. Quinlan), pp. 137-156. Turing Institute Press in association with Addison-Wesley Publishing Company, Sidney.

Minsky, M.L. and Papert, S.A. (1969). Perceprons, An Introduction to Computational Geometry. MIT Press, Cambridge, Mass. Expanded edition (1988), MIT Press, Cambridge, Mass.

Mulder, F.W. en Braspenming, P.J. (1988). Een complex Blackboard Systeem woor Beeld Reeks Interpretatic. Te verschijnen in Proceedings Artificial Intelligence Toepassingen ' 88 , 's-Gravenhage.

Nagel, E. (1961). The Structure of Science. Routledge and Kegan Paul Ltd., London.

Newmann, J. von and Morgenstern, O. (1944). Theory of Games and Economic Behavior. Second edition 1947. Princeton University Press, Princeton.

Newborn, M. (1985). A Parallel Search Chess Program. Proc. ACM Anrual Conference, Denver, pp. 272-277.

Newell, A. and Simon, H.A. (1972). Human Problem Solving. Prentice-Hall, Inc., Englewood Clifrs, New Jersey.

Plato, Meno $80 \mathrm{~d}$ sq.

Pylyshyn, Z.W. (1984). Computation and Cognition, Toward a Foundation for Cognitive Science. MIT Press, Cambridge, Mass.

Quinlan, J.R. (1979). Discovering, rules by induction from large collections of examples. Expert Systems in the Micro-electronic Age (ed. D. Michic), pp. 168-201. Edinburgh University Press.

Quinlan, J.R. (1984). Leaming Efficient Classification Procedures and their Application to Chess End Games. Machire Learning (eds. R.S. Michalski, J.G. Car. bonell, T.M. Mitchell), pp. 463-482. Tioga Publishing Company, Palo Alto California. 
Rich, E. (1983). Artificial Intelligence. McGraw-Hill Book Company, New York.

Riet, R.P. van de (1971). Wiskunde, Computers en Computerwiskunde. Inaugurele Rede, Vrije Universiteit Amsterdam, Amsterdam.

Robinson, J.A. (1965). A Machine-oriented Logic Based on the Resolution Principle. Journal of the ACM, Vol. 12, pp. 23-41.

Rosenblatt, F. (1958). The Perceptron, a Probabilistic Model for Information Organization and Storage in the Brain. Psychological Review, Vol. 65, pp. 368-408.

Rosenblatt, F. (1962). Principles of Neurodynamics, Spartan Books, New York.

Rosenblith, W.A. (1966). On Cybernetics and the Human Brain. The American Scholar, p. 247.

Samuel, A.L. (1959). Some Studies in Machine Learning Using the Game of Checkers. IBM Journal of Research and Development, 3, pp. 211-229. Reprinted in Computers and Thought (eds. E.A. Feigenbaum and J. Feldman) (1963), pp. 71105, McGraw-Hill Book Company, New York-San Francisco-Toronto-LondonSydney.

Samuel, A.L. (1967). Some Studies in Machine Learning Using the Game of Checkers. II - Recent Progress. IBM Journal of Research and Development, Vol. 2, No. 6, pp. 601-617. Reprinted in Human and Artificial Intelligence (ed. F.J. Crosson) (1970), pp. 81-116, Appleton-Century-Crofts, Educational Division, Meredith Corporation, New York.

Schaeffer, J. (1987). Speculative Computing. ICCA Journal, Vol. 10, No. 3, pp. 118-124.

Schank, R.C. (1979). Natural Language, Philosophy and Artificial Intelligence. Philosophical Perspectives in Artificial Intelligence (ed. M. Ringle). Humanities Press, Atlantic Highlands, N.J.

Searle, J.R. (1980). Minds, Brains and Programs. Behavioral and Brain Sciences, 3, pp. 417-457.

Searle, J.R. (1984). Minds, Brains and Science. Harvard University Press, Cambridge, Mass.

Shannon, C.E. (1950). Programming a Computer for Playing Chess. Philosophical Magazine, 41, pp. 256-275.

Skinner, B.F. (1953). Science and Human Behavior. Macmillan, New York.

Sol, H.G. (1984). Expertise rond informatiesysteem ontwerp. Inaugurele Rede TH Delft. Samson Uitgeverij, Alphen aan de Rijn. 
Steels, L. (1988). Steps Towards Common Sense. Proceedings of the $8^{\text {th }}$ Conference on Artificial Intelligence (ECAI 88), pp. 49-54, München.

Stefanou, N., Braspenning, P.J., Zeller, R. and Dederichs, P.H. (1987). Treatment of Lattice Relaxations in Dilute Alloys within the Korringe-Kohn-Rostoker Green's-function method. Physical Review B, Vol. 36, No. 12, pp. 6372-6382.

Thompson, K. (1986). Retrograde Analysis of Certain Endganes. ICCA Jounal, Vol. 9, No. 3, pp. 131-139.

Toulouse, G., De Haene, S., and Changeux, J..P. (1986). Spin glass model of learning by selection. Proc. Natl. Acad. Sci. USA, Voll 83, pp. $1695-1698$.

Turing, A.M. (1936). On computable numbers, with an application to the Entscheidungsproblem. Proc. London math. Soc. (2), 42, pp. $230-267$.

Turing, A.M. (1950). Computing Machinery and Intelligence. Mind, 59, pp. 430460. Reprinted in The World of Mathematics (ed. J.R. Newman), 4, 19, pp. $2099-$ 2133, George Allen and Unwin Ltd., London; in Computers and Thought (eds. E.A. Feigenbaum and J. Feldman), pp. 11-35, McGraw-Hill Book Company, New York-San Francisco-Toronto-London-Sydney; in Minds and Machines (ed. A.R. Anderson), pp. 4-30, Prentice-Hall, Inc., Englewood Cliffs, New Jersey; in The Mind's I (eds. D.R. Hofstadter and D.C. Dennett), pp. 53-67, Basic Books, Inc., Publishers, New York.

Turing, A.M. (1953). Digital Computers Applied to Games. Faster than Thought (ed. B.V. Bowden), Sir Isaac Pitman, London.

Uiterwijk, J.W.H.M. (1988a). Conversion between Analytic and Non-Analytic Proofs in Artificial Intelligence. Afstudeerverslag Universiceit Twente, Knowledge-based Systems groep, Faculteit der Informatica.

Uiterwijk, J.W.H.M. (1988b). CANAPE: Conversion between Analytic and NonAnalytic Proofs: the Expert. PROLOG-implementatie (in ontwikkeling), Rijksuniversiteit Limburg, wakgroep informatica.

Verrijn Stuart, A.A. (1971). Lezen en Schrijven. Inaugurele Rede, Rijksuniversiteit Leiden. Wolters-Noordhoff, Groningen.

Vondel, J. van den (1587-1679). Werken. Opnieuw uitgegeven (ed. A. Verwey) (1937), p. 936. H.J.W. Becht, Amsterdam.

Warnock, T. and Wendroff, B. (1988). Search Tables in Computer Chess. ICCA Journal, Vol. 11, No. 1, pp. 10-13.

Weijters, A. (1988). Denotation Resolution of Definite Descriptions in DRAFT: A Dynamic Process. Voordracht ujjens The International Workshop on Discourse Processing and the Representation of Coherence. Tilburg, $1-3$ september. 
Wiclinga, B.J. and Breuker, J.A. (1986). Models of Expertise. Proceedings of the $7^{\text {th }}$ Conference on Artificial Intelligence (ECAI 86), North Holland, Amsterdam.

Winograd, T. (1972). Understanding Natural Language. Cognitive Psychology, Vol. 1, pp. 1-191. Also published by Academic Press (1972), New York.

Winston, P.H. (1984). Artificial Intelligence. Addison-Wesley Publishing Company, Reading, Mass. 